Brigham Young University Law School

BYU Law Digital Commons

Faculty Scholarship

$1-1-2014$

Comparative Institutional Competency and Sovereignty in Indian Affairs

Michalyn Steele

BYU Law, steelem@law.byu.edu

Follow this and additional works at: https://digitalcommons.law.byu.edu/faculty_scholarship

Part of the Indian and Aboriginal Law Commons

Recommended Citation

Michalyn Steele, Comparative Institutional Competency and Sovereignty in Indian Affairs, 85 U. CoLo. L. Rev. 759 (2014).

This Article is brought to you for free and open access by BYU Law Digital Commons. It has been accepted for inclusion in Faculty Scholarship by an authorized administrator of BYU Law Digital Commons. For more information, please contact hunterlawlibrary@byu.edu. 


\title{
COMPARATIVE INSTITUTIONAL COMPETENCY AND SOVEREIGNTY IN INDIAN AFFAIRS
}

\author{
MICHALYN STEELE*
}

While vigorous debate surrounds the proper scope and ambit of inherent tribal authority, there remains a critical antecedent question: whether Congress or the courts are ultimately best situated to define the contours of inherent tribal authority. In February 2013, Congress enacted controversial tribal jurisdiction provisions as part of the Violence Against Women Act reauthorization recognizing and affirming inherent tribal authority to prosecute all persons, including non-Indian offenders, for crimes of domestic violence in Indian country. This assertion by Congress of its authority to set the bounds of tribal inherent authority-beyond where the United States Supreme Court has held tribal inherent authority to reachunderscores the importance of addressing the question of which branch ought to resolve the issue. This Article proposes a framework drawn from Supreme Court jurisprudence in the field of state sovereignty to argue that when sensitive issues of sovereignty are at stake, the comparative competence of the respective branches must be considered. Unlike any preceding work in this field, this Article proposes a model based on the indicia of institutional competence to suggest that Congress, rather than the courts, is the branch best suited to determine the scope of inherent tribal sovereignty.

INTRODUCTION

I. THE TRIBAL SOVEREIGNTY DEBATE .............................765

A. Foundations of Tribal Sovereignty ..........................766

\footnotetext{
* Faculty Fellow, Brigham Young University Law School. I would like to thank my colleagues at Brigham Young University for their helpful comments on earlier drafts, in particular, Lisa Grow Sun, RonNell Anderson Jones, Brigham Daniels, David Moore, Shima Baradaran, and Gordon Smith. I also thank Dean Nell Jessup Newton of Notre Dame Law School for her insightful comments and encouragement. I am also grateful to my colleagues at the UCLA Indian Law Scholars Conference (June 2013) for their insights. Poponatui Sitake, Joseph Orien, Shalise Conger, and Lucia Maloy provided excellent research assistance.
} 
B. The Contested Contours of Tribal Sovereignty........769

II. THE COMPARATIVE INSTITUTIONAL COMPETENCY MODEL FOR DEFINING SOVEREIGNTY ..........................779

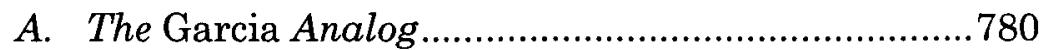

B. Application of the Model: Indicia of Comparative Institutional Competency..........................................783

1. Constitutional Commitment of the Relevant

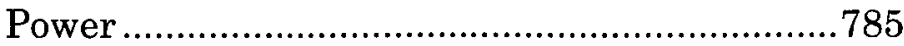

2. Judicially Discoverable, Objective Standards ...792

3. The Need for Political Accountability ................800

4. Tailoring Solutions to Balance Competing Interests. 804

5. Adapting to Changing Circumstances ...............809

6. The Prominence of Resource Allocation Issues .812

7. Subject Matter Expertise ...................................814

CONCLUSION 815

\section{INTRODUCTION}

The statistics tell a grim tale of the consequences of a jurisdictional gap. Native American and Alaska Native women are victims of violent crime at a rate two-and-a-half times the national average. ${ }^{1}$ Non-Indians are estimated to commit at least 70 percent of the violent crimes against Native Americans and Alaska Natives. ${ }^{2}$ Less than 50 percent of crimes of domestic violence against Native American women are prosecuted. ${ }^{3}$ In July 2011, the Senate Indian Affairs Committee held a hearing on the crisis of violence against Native women. ${ }^{4}$

1. Lawrence A. Greenfield \& Steven K. Smith, American Indians and Crime, U.S. DEP'T OF JUSTICE 2 (Feb. 1999), bjs.ojp.usdoj.gov/content/ pub/pdf/aic.pdf; Steven W. Perry, American Indians and Crime: $A$ BJS Statistical Profile, 1992-2002, U.S. DEP'T OF JUSTICE 33-34 (Dec. 2004), http://www.bjs.gov/ content/pub/pdf/aic02.pdf. The Justice Department estimates that "one in three Native American women are raped during their lifetimes-two-and-a-half times the likelihood for any average American woman." Sierra Crane-Murdock, On Indian Land, Criminals Can Get Away with Almost Anything, ATLANTIC (Feb. 22, 2013, 9:16 AM), http://www.theatlantic.com/national/archive/2013/02/on-indianland-criminals-can-get-away-with-almost-anything/273391.

2. Greenfield \& Smith, supra note 1 , at $v$-vi (noting that the study included Alaska Natives and Aleuts in the category of "American Indians" for purposes of the statistical report).

3. 159 CONG. REC. S571, 579 (daily ed. Feb. 11, 2013) (statement of Senator Maria Cantwell).

4. Native Women: Protecting, Shielding, and Safeguarding Our Sisters, Mothers, and Daughters: Hearing Before the S. Comm. on Indian Affairs, 112th 
The Committee examined a University of Oklahoma study that had found that three out of five Native women had been assaulted by their spouses or intimate partners. ${ }^{5}$ Associate Attorney General Thomas J. Perrelli testified that violence against Native women too often "goes unaddressed, with beating after beating, each more severe than the last, ultimately leading to death or severe physical injury." 6 Amnesty International's scathing report about the crisis of violence against Native women in the United States recounts the stories of two Native American women raped in Oklahoma in $2005 .{ }^{7}$ In separate but similar crimes, a group of three nonIndian men abducted women, blindfolded them, and raped them. ${ }^{8}$ In the aftermath of the crimes, support workers were concerned that, because the women had been blindfolded and abducted, they would not be able to say whether the rapes had occurred on federal, state, or tribal land. ${ }^{9}$

Tribes have been hamstrung in their efforts to curb this tide of violence in Indian country by a judicially-crafted limitation on tribal inherent authority that denies Indian tribes criminal jurisdiction over non-Indians who commit crimes against Indians in tribal territory. ${ }^{10}$ As a result of this

Cong. 1-2 (2011) [hereinafter Native Women].

5. Id. at 7 (statement of Thomas J. Perrelli, Associate Attorney General, U.S. Department of Justice).

6. Id.

7. Maze of Injustice: The Failure to Protect Indigenous Women from Sexual Violence in the USA, AMNESTY INT'L 27 (2007), http://www.amnestyusa. org/pdfs/MazeOfInjustice.pdf.

8. Id.

9. Id. The jurisdictional gap also has devastating consequences for nonIndian women. In June 2012, a non-Indian girl, only sixteen years old, was found by a tribal officer on the Fort Berthold Indian Reservation in western North Dakota. Crane-Murdock, supra note 1 . She had been raped by non-Indians, which meant that the tribal officer had no jurisdiction. Id. Furthermore, although there has been a noticeable rise in non-Indian perpetrators of violence against women on the Fort Berthold reservation, the tribe has been unable to prosecute such crimes. Id.

10. See Oliphant v. Suquamish Indian Tribe, 435 U.S. 191, 212 (1978) (holding that inherent authority of tribes to exercise criminal jurisdiction over non-Indians had been implicitly divested as inconsistent with the superior sovereignty of the United States); Rebecca A. Hart, No Exceptions Made: Sexual Assault Against Native American Women and the Denial of Reproductive Healthcare Services, 25 WIS. J. L. GENDER \& SOC'Y 209, 257 (2010) ("Currently, tribal law enforcement and tribal courts are hamstrung because of the jurisdictional maze that makes prosecution of non-Indian offenders impossible unless undertaken by the federal government and hampers prosecution of Native American offenders."). 
jurisdictional gap, many crimes-especially crimes of violence against Native American women-go unpunished. ${ }^{11}$

The problem is a product of the modern United States Supreme Court's tendency to treat tribal authority as suspect and anachronistic. ${ }^{12}$ The Supreme Court has repeatedly diminished tribal sovereignty. By contrast, since the 1960's, Congress has pursued a policy of enhanced tribal selfdetermination and self-government, including fortifying tribal courts and other tribal institutions. ${ }^{13}$ Congress recently enacted a modest but controversial modification of the policy against tribal criminal jurisdiction over non-Indians in the reauthorization of the Violence Against Women Act (VAWA). ${ }^{14}$

The tribal jurisdiction provisions affirmed the inherent authority of tribes to prosecute all persons, including nonIndians, for crimes of domestic violence against Indians in

11. Amanda M.K. Pacheco, Broken Traditions: Overcoming the Jurisdictional Maze to Protect Native American Women from Sexual Violence, 11 J. L. \& Soc. Challenges 1, 2 (2009).

12. See, e.g., David H. Getches, Conquering the Cultural Frontier: The New Subjectivism of the Supreme Court in Indian Law, 84 CAL. L. REV. 1573, 1573-74 (1996) ("The right of Indians to tribal self-government has always been vulnerable to abrogation by acts of Congress. But the Courts have generally served as the conscience of federal Indian law, protecting tribal powers and rights. . . . The Supreme Court has recently begun to depart from this traditional standard, abandoning entrenched principles of Indian law in favor of an approach that bends tribal sovereignty to fit the Court's perceptions of non-Indian interests.").

13. See, e.g., Tribal Law and Order Act of 2010, Pub. L. No. 111-211, 124 Stat. 2261 (codified as amended in scattered sections of 25 U.S.C.). In enacting the law, Congress found that "tribal justice systems are often the most appropriate institutions for maintaining law and order in Indian country" and that "the complicated jurisdictional scheme that exists in Indian country has a significant negative impact on the ability to provide public safety to Indian communities." 25 U.S.C. $\$ 202(a)(2)(B),(4)(A)$. Among the purposes Congress identified for this Act is to "empower tribal governments with the authority, resources, and information necessary to safely and effectively provide public safety in Indian country." Id. $\S 202(\mathrm{~b})(3)$.

14. 159 CoNG. REC. S571, 571-86 (daily ed. Feb. 11, 2013) (debating the Coburn Amendment seeking to strip the tribal jurisdiction amendments from the Senate bill reauthorizing the Violence Against Women Act); Jonathan Weisman, Measure to Protect Women Stuck on Tribal Land Issue, N.Y. TIMES, Feb. 10, 2013, http://www.nytimes.com/2013/02/11/us/politics/violence-against-women-act-heldup-by-tribal-land-issue.html. Violence Against Women Reauthorization Act of 2013, Pub. L. No. 113-4, 127 Stat. 54 (codified as amended in scattered sections 42, 25, 22, and 18 U.S.C.), passed the Senate on February 12, 2013, and passed the House on February 28, 2013. Ashley Parker, House Renews Violence Against Women Measure, N.Y. TIMES, Feb. 28, 2013, http://www.nytimes.com/2013/03/01/ us/politics/congress-passes-reauthorization-of-violence-against-women-act.html. 
tribal territory. ${ }^{15} \mathrm{~A}$ key issue in the congressional debate was whether Congress had the constitutional authority to recognize and affirm the inherent authority of tribes to exercise limited criminal jurisdiction over non-Indians, given the Supreme Court precedent that such authority is not within the retained inherent authority of tribes. ${ }^{16}$ In enacting the VAWA provisions, Congress has asserted its own authority to weigh the constitutional and policy considerations regarding the boundaries of inherent tribal authority. The tribal domestic violence provision of VAWA has recognized and affirmed a limited inherent criminal jurisdiction over non-Indians notwithstanding Supreme Court precedent to the contrary. ${ }^{17}$

The VAWA debate is but the latest salvo in the ongoing struggle between the Supreme Court and Congress about which branch will set the limits of inherent tribal authority-a debate that spans not only questions of tribal criminal jurisdiction but also questions of tribal civil authority. ${ }^{18}$ Yet, while there has been a great deal of heated debate in both judicial opinions ${ }^{19}$ and scholarly commentary ${ }^{20}$ on the question

15. The tribal jurisdiction provisions of VAWA amended the Indian Civil Rights Act to clarify that "the powers of self-government of a participating tribe include the inherent power of that tribe, which is hereby recognized and affirmed, to exercise special domestic violence criminal jurisdiction over all persons." Violence Against Women Reauthorization Act of 2013, Pub. L. No. 113-4, 127 Stat. 54 (codified as amended at U.S.C. $\S 1304(b)(1))$ (emphasis added).

16. See Oliphant v. Suquamish Indian Tribe, 435 U.S. 191, 212 (1978), superseded by statute on other grounds as stated in United States v. Lara, 541 U.S. 193, 205-07 (2004) (holding that inherent authority of tribes to exercise criminal jurisdiction over non-Indians had been implicitly divested as inconsistent with the superior sovereignty of the United States).

17. Parker, supra note 14.

18. See, e.g., Montana v. United States, 450 U.S. 544 (1981) (finding tribal inherent authority over non-Indian activities on non-Indian owned fee land within the reservation impliedly divested in civil regulatory context).

19. See, e.g., Lara, 541 U.S. at 210 (upholding Congress's power to allow tribes to exercise criminal jurisdiction over nonmember Indians); Duro v. Reina, 495 U.S. 676, 688 (1990), superseded by statute on other grounds as stated in Lara, 541 U.S. at 205-07 (holding that tribal criminal jurisdiction does not extend to nonmember Indians); Montana, 450 U.S. at 564-65 (holding that the Crow Tribe did not have civil jurisdiction to regulate hunting and fishing by nonmembers of a tribe on land within a reservation but no longer owned by the tribe).

20. See, e.g., Sarah Krakoff, A Narrative of Sovereignty: Iluminating the Paradox of the Domestic Dependent Nation, 83 OR. L. REV. 1109 (2004) (examining the effects of tribal jurisdiction law on the Navajo Nation); Getches, supra note 12 (discussing the Court's subjectivist approach to Indian jurisdiction); L. Scott Gould, Tough Love for Tribes: Rethinking Sovereignty After Atkinson and Hicks, 37 NEW ENG. L. REV. 669, 670 (2003) (analyzing the effects of the Court's decision 
of the scope and ambit of inherent tribal authority, no one has set forth a coherent framework for answering the critical antecedent question: whether the courts or Congress should be empowered to define the contours of inherent tribal authority. ${ }^{21}$ This Article proposes such a framework, drawn from Supreme Court jurisprudence in the analogous field of state sovereignty. In the pivotal case of Garcia v. San Antonio Metropolitan Transit Authority, ${ }^{22}$ the Court held that the judiciary was not well suited to appraise what state functions were "traditional governmental functions" that must be immunized from federal regulation. ${ }^{23}$ The Garcia Court determined that it was for the political process rather than the judiciary to determine "where the frontier between state and federal power lies." 24 In other words, because of the comparative institutional competence of the legislature to address sensitive and difficult questions of allocating sovereignty, and the "elusiveness of objective criteria" for judicial resolution of the issues, the judiciary should defer to the political branches on the question of inviolable state sovereignty. ${ }^{25}$ This Article urges the adoption of this

that "the Navajo Tribe lacked authority to impose an occupancy tax on guests of a hotel located on fee land within the reservation"); Nicole E. Ducheneaux, Note, Smith v. Salish Kootenai College: Self Determination as Governing Principle or Afterthought in Tribal Civil Jurisdiction Jurisprudence?, 68 MONT. L. REV. 211 (2007) (examining the effects of a Ninth Circuit decision on tribal civil jurisdiction).

21. In recent decades, federal Indian law scholars and tribal advocates have perceived the Supreme Court as too intrusive of Congress's role as policymaker in Indian affairs. See, e.g., Philip S. Deloria \& Nell Jessup Newton, The Criminal Jurisdiction of Tribal Courts Over Non-Member Indians: An Examination of the Basic Framework of Inherent Tribal Sovereignty Before and After Duro v. Reina, 38 FED. B. NEWS \& J. 70, 72-73 (1991); Charles Wilkinson, "Peoples Distinct From Others": The Making of Modern Indian Law, 2006 UTAH L. REV. 379, 384-85. However, this scholarly concern has not produced a coherent framework for assessing why decisions about inherent tribal sovereignty should rest with the courts or Congress.

22. 469 U.S. 528, 540-43 (1985), superseded by statute on other grounds as stated in Acton v. City of Columbia, Mo., 436 F.3d 969 (8th Cir. 2006).

23. Id.

24. Id. at 550 .

25. Id. at 548-50. "Comparative institutional competence" refers to the process of determining which decisionmakers among the federal branches are best suited to render a judgment or formulate a policy. Describing comparative institutional competence as a motivation for judicial deference, Professor Paul Horwitz wrote:

[W] hen courts defer to other decisionmakers on epistemic grounds related to comparative institutional competence, they are actually doing 
comparative institutional competency model for sovereignty questions in the realm of Indian affairs and argues that application of this model demonstrates that the Court should defer to Congress as the branch best suited to resolve the complex policy considerations involved in setting the limits of inherent tribal authority.

Part I of this Article outlines the contours of the problem of defining tribal inherent authority, exploring the fundamental role that issues of tribal sovereignty have played in federal Indian law jurisprudence and tracing the Supreme Court precedent attempting to delineate both the boundaries of inherent tribal authority and the respective roles of Congress and the Court in determining those boundaries. Part II explains the Garcia analogue to the tribal sovereignty determination; sets forth the comparative institutional competency model for determining which branch should resolve questions about the limits of tribal inherent authority; and applies that model to determine that Congress, rather than the Courts, should be the final arbiter of the boundaries of inherent tribal authority. Throughout, the tribal jurisdiction provisions of the VAWA are used as an illustrative example to test arguments about the comparative institutional advantage of Congress to resolve these matters.

\section{The TRIBAL SOVEREIGNTY DEBATE}

This Part lays out the terms of the debate over the status of tribal sovereignty today. Part I.A establishes the doctrinal foundation, in constitutional text and Supreme Court authority, for the quasi-sovereign nature of Indian tribes in the American constitutional scheme and argues that sensitive and thorny issues stemming from the interplay of tribal and United States sovereignty lie at the heart of federal Indian law jurisprudence. Part I.B expands on this theme by tracing the key Supreme Court decisions that frame the current debate

two things. First, they are suggesting that some other decisionmaker actually possesses important information, experience, and skills that will help it decide some relevant question correctly. Second, they are suggesting that the other decisionmaker is not just a good one: it is also a superior decisionmaker, relative to the court.

Paul Horwitz, Three Faces of Deference, 83 NOTRE DAME L. REV. 1061, 1085-86 (2008). 
about the proper locus of power for defining the scope of inherent tribal authority.

\section{A. Foundations of Tribal Sovereignty}

At the heart of almost every debate in federal Indian law is the question of tribal sovereignty and the extent to which tribes retain aspects of the sovereignty they possessed before the United States came into being. Both the Constitution and longstanding Supreme Court precedent acknowledge that Indian tribes are not mere membership organizations that assert internal governance only over matters of membership and internal relationships. ${ }^{26}$ Instead, they exercise some degree of sovereignty over people and territory. 27

The authority to exercise that sovereignty-so-called inherent tribal authority-originates with the aboriginal power of tribes to govern people and territory. ${ }^{28}$ The inherent powers of tribal self-government do not derive from a delegation of

26. "[Tribes] are a good deal more than 'private, voluntary organizations," United States v. Mazurie, 419 U.S. 544, 557 (1975). See also Philip P. Frickey, (Native) American Exceptionalism in Federal Public Law, 119 HARV. L. REV. 431, 479 (2005) (taking issue with the Court's conception in Duro v. Reina, 495 U.S. 676 (1990), that tribes are viewed as membership organizations: "If a tribe is a sovereign, of course, citizenship, membership, or actual consent should not matter to its authority to sanction breaches of the peace. If it is not a sovereign, membership can matter, but not enough to make a difference in these contexts. ... So it is completely unclear why a tribe-if analogized to a private association rather than a sovereign-is allowed to incarcerate a member...."); Deloria \& Newton, supra note 21, at 70-71 (Indian tribes are not "arms of the federal or of the state governments. They exercise their own inherent sovereign powers. ...").

27. Mazurie, 419 U.S. at 557.

28. The federal common law doctrine recognizing the inherent governing authority of tribes as distinct political communities entitled to self-government traces its roots to the European theorists seeking to build a legal framework for dealing with the inconvenient inhabitants of "discovered" lands, to which they asserted the Pope had ultimate legal dominion. See Steven T. Newcomb, The Evidence of Christian Nationalism in Federal Indian Law: The Doctrine of Discovery, Johnson v. McIntosh, and Plenary Power, 20 N.Y.U. REv. L. \& Soc. CHANGE 303 (1993). As Felix Cohen, the leading early scholar in the field of Indian law, notes, the European legal community's theoretical debate about the sovereign rights, if any, of tribes was marked by sharp disagreements and colored by the scholars' "preference for governments and land use patterns in the European mold." FELIX COHEN, COHEN'S HANDBOOK OF FEDERAL INDIAN LAW $\S 4.01[1]$ [a], at 207 (Nell Jessup Newton ed., 2012). Still, some enduring principles emerged from those debates that would prove useful, both for crass pecuniary purposes and to assuage the moral qualms, first of the English colonists and then the newly independent States. 
power by the United States or from the Constitution. Rather, these powers predate the Constitution and are acknowledged, at least implicitly, in the Constitution itself. ${ }^{29}$ The Indian Commerce Clause, for example, presumes some degree of sovereignty in Indian tribes when it enumerates the power of Congress to regulate commerce "with foreign Nations, and among the several States, and with the Indian Tribes." 30 This Clause treats Indian tribes as sovereigns, in some ways like states and foreign nations. In other words, tribes are governmental entities with whom Congress may regulate commerce.

Similarly, the well-settled and longstanding recognition that Indian tribes are proper partners for treaty-making suggests that tribes are sovereign entities with whom the United States can negotiate and execute sovereign-to-sovereign agreements. ${ }^{31}$ Indeed, in Worcester v. Georgia, Justice Marshall argued that the Constitution itself accepts the sovereignty of tribes and recognizes their inherent powers of self-government as it

[A]dmits [tribes'] rank among those powers who are capable of making treaties. The words "treaty" and "nation" are words of our own language, selected in our diplomatic and legislative proceedings, by ourselves, having each a definite and well understood meaning. We have applied them to Indians, as we have applied them to the other nations of the earth. They are applied to all in the same sense. ${ }^{32}$

Moreover, the sui generis character of Congress's dealings with Indian tribes is also indicative of the sovereign status of tribes: the relationship between the United States and Indian tribes is not a relationship based on the race of Indian people so much as it is on the political identity of tribes as governments. ${ }^{33}$ As a consequence, the many enactments of Congress for the regulation and benefit-and sometimes to the

29. United States v. Lara, 541 U.S. 193, 200-02 (2004).

30. U.S. ConST. art. I, § 8, cl. 3.

31. Worcester v. Georgia, 31 U.S. 515, 519 (1832), abrogated on other grounds as recognized by Nevada v. Hicks, 553 U.S. 353, 361-62 (2001).

32. Id. at 559-60.

33. See Morton v. Mancari, 417 U.S. 535, 551 (1974) (holding tribes have a "unique legal status ... under federal law . . . based on a history of treaties and the assumption of a 'guardian-ward' status"). 
detriment-of Indian tribes are shielded from the scrutiny that normally attaches to a race-based enactment because they carry out government-to-government obligations and fulfill the sovereign-to-sovereign relationship. ${ }^{34}$

Despite these indicia of retained tribal sovereignty, the United States asserts that the sovereignty of tribes is necessarily limited by the sovereign power of the federal government. ${ }^{35}$ Under federal common law, the sovereignty of tribes is subordinate to the sovereignty of the United States, and some inherent powers of tribal sovereignty have been divested as a result. ${ }^{36}$ Within federal Indian jurisprudence, the sovereign nature of tribes derives in large part from Justice Marshall's early strivings with the nature and authority of Indian tribes in the nascent democracy. ${ }^{37}$

Justice Marshall described tribes as "domestic dependent nations" in the earliest cases involving Indian tribes as entities before the Supreme Court. 38 This legal construct, acknowledged by the Court and implemented by Congress, envisions self-governing, quasi-sovereign tribal nations exercising their own inherent governmental powers, even while subject to the superior sovereignty of the United States. ${ }^{39}$ Under this view, tribes retain their aboriginal sovereignty over matters of internal self-government, but the powers of external relations are "necessarily diminished" by the superior sovereignty asserted by the United States. ${ }^{40}$ In many respects,

34. See, e.g., Philip P. Frickey, Doctrine, Context, Institutional Relationships, and Commentary: The Malaise of Federal Indian Law Through the Lens of Lone Wolf, 38 TULSA L. REV. 5, 5-9 (2002) [hereinafter Frickey, Malaise of Federal Indian Law] (noting the racist undercurrents of both Lone Wolf v. Hitchcock, 187 U.S. 553 (1903), and Dred Scott v. Sandford, 60 U.S. 393 (1857)); see also Morton, 417 U.S. at 551-53.

35. See, e.g., United States v. Wheeler, 435 U.S. 313, 323 (1978), superseded by statute on other grounds as stated in United States v. Lara, 541 U.S. 193, 193 (2004); Oliphant v. Suquamish Indian Tribe, 435 U.S. 191, 209 (1978), superseded by statute on other grounds as stated in United States v. Lara, 541 U.S. 193, 20507 (2004).

36. See, e.g., Wheeler, 435 U.S. at 323; Oliphant, 435 U.S. at 209.

37. The so-called "Marshall Trilogy" includes three key early cases involving tribes before the Supreme Court. The trilogy includes: Johnson v. M'Intosh, 21 U.S. 543 (1823); Cherokee Nation v. Georgia, 30 U.S. 1 (1831); and Worcester v. Georgia, 31 U.S. 515 (1832).

38. See e.g., Cherokee Nation, 30 U.S. at 17.

39. See, e.g., Wheeler, 435 U.S. at 323.

40. The key sovereign traits thought to be diminished by the Marshall Trilogy were the power to alienate lands to any entity other than the federal government and the power to form alliances and treaties with foreign powers. Williams v. Lee, 
of course, labeling tribes as "domestic dependent nations" simply restates the question about the extent of retained tribal sovereignty, rather than answers it. The ongoing challenge is to define the powers of an entity that is sovereign, but not fully so, within the American polity.

\section{B. The Contested Contours of Tribal Sovereignty}

The history of federal Indian law is, in large part, the story of this struggle to determine which powers of tribal sovereignty endure, to define the reach of those powers, and to decide over whom those retained powers may be exercised. As tribal governments and institutions have developed, both Congress and the courts have struggled to identify the reach of tribes' inherent powers over people and territory. ${ }^{41}$ Tribes asserting authority to $\operatorname{tax}$ or regulate activities within their borders, adjudicate disputes arising in their territory, and punish criminal offenses against tribal members have frequently been stymied by the Supreme Court's shifting pronouncements about the extent of inherent authority in criminal and civil matters and the seemingly ad hoc rationales of the judicial struggle to find objective criteria for resolving such questions. ${ }^{42}$

In early cases considering the scope of inherent tribal authority, the Supreme Court developed a presumption in favor of recognizing tribal authority, so long as Congress had not expressly divested that authority. ${ }^{43}$ Felix Cohen summarized what he called "the whole course of judicial decision on the nature of Indian tribal powers" as being

358 U.S. 217,218 (1959).

41. See, e.g., Oliphant, 435 U.S. at 196-202; Duro v. Reina, 495 U.S. 676 (1990), superseded by statute on other grounds as stated in United States v. Lara, 541 U.S. 193, 205-07 (2004); Lara, 541 U.S. at 196; 25 U.S.C. § 1301(2), (4) (2012).

42. See, e.g., Montana v. United States, 450 U.S. 544, 564 (1981); see also Nevada v. Hicks, 533 U.S. 353, 358-59 (2001) (tribal ownership of land is not sufficient to assert tribal regulatory jurisdiction over nonmembers); Duro, 495 U.S. at 685-86 (applying the implicit divestiture doctrine to tribal regulation of nonmembers); Oliphant, 435 U.S. at 195 (Indian tribes do not have criminal jurisdiction over non-Indians absent express delegation from Congress); Strate v. A-1 Contractors, 520 U.S. 438, 442 (1997) (tribe did not have adjudicatory jurisdiction over a vehicle accident on tribal land); Atkinson Trading Co. v. Shirley, 532 U.S. 645, 653 (2001) ("An Indian tribe's sovereign power to taxwhatever its derivation-reaches no further than tribal land.").

43. Talton v. Mayes, 163 U.S. 376, 382-85 (1896). 
"marked by adherence to three fundamental principles." 4 Those "fundamental principles" include: first, that an Indian tribe possesses the powers of any sovereign state; second, that having been "conquered," tribes are subject to the legislative power of the United States and that their external powers of sovereignty have been terminated, though the local powers of self-government endure; and third, the powers of selfgovernment are subject to qualification by express legislation of Congress and treaties. ${ }^{45}$ However, except as "expressly qualified, full powers of internal sovereignty are vested in the Indian tribes and their duly constituted organs of government." 46

For a period, the modern Supreme Court appeared ready to uphold the principles of tribal sovereignty rooted in the Marshall Trilogy. ${ }^{47}$ The Supreme Court abruptly abandoned these fundamental principles in 1978 when, in a key decision about the scope of inherent tribal authority, it weighed in decisively against inherent tribal criminal jurisdiction over non-Indians. ${ }^{48}$ In Oliphant $v$. Suquamish Indian Tribe, the Court held that tribes did not have "inherent jurisdiction to try and to punish non-Indians" because such jurisdiction was "inconsistent with" tribes' status as diminished sovereigns. ${ }^{49}$ Oliphant involved the consolidated cases of two non-Indian residents of the Port Madison Reservation of the Suquamish Tribe in Washington. ${ }^{50}$ The defendants were charged, respectively, with assaulting tribal officers and evading tribal police during a car chase that ended when the suspects crashed into a tribal police vehicle. ${ }^{51}$ The petitioners challenged the tribe's criminal jurisdiction over them in the U.S. district court and subsequently appealed to the Ninth Circuit. Both courts

44. Felix Cohen, Handbook of Federal Indian LAW 123 (1942) (citations omitted).

45. Id.

46. Id.

47. See, e.g., Williams v. Lee, 358 U.S. 217 (1959) (recognizing exclusive jurisdiction of tribal courts in matters arising on reservations against Indian defendants); Menominee Tribe of Indians v. United States, 391 U.S. 404 (1968) (upholding treaty rights of terminated tribe); see also Matthew L.M. Fletcher, The Supreme Court and the Rule of Law: Case Studies in Indian Law, 55 APR FED. LAW. 26, 28 (2008).

48. Oliphant v. Suquamish Indian Tribe, 435 U.S. 191, 212 (1978).

49. Id. at $199,212$.

50. Id. at 194 .

51. Id. 
affirmed the tribe's inherent criminal jurisdiction over Oliphant. ${ }^{52}$ In finding tribal court jurisdiction over Oliphant, the Ninth Circuit determined that the "power to preserve order on the reservation ... is a sine qua non of the sovereignty that the Suquamish originally possessed."53

The Supreme Court reversed. ${ }^{54}$ In overturning the Ninth Circuit's view of the inherent sovereignty of the tribe, the Court speculated that Congress could delegate authority to Indian tribes to exercise criminal jurisdiction over non-Indians, but that tribes' inherent authority was impliedly divested by virtue of tribes having been incorporated into the United States. ${ }^{55}$ In so holding, the Court upended the traditional presumption in favor of tribal authority unless Congress had expressly divested that authority. Oliphant has come to stand for the Court's highly controversial theory of "implicit divestiture" of inherent tribal authority and its intrusion into the policymaking powers of Congress in Indian affairs. ${ }^{56}$ Rather than looking to whether Congress had expressly divested tribes of the inherent authority, "the Court reasoned that a statute was unnecessary" to find the power implicitly divested; instead, the Court looked to bills that had never been passed and what it called "shared presumptions" of the other branches that tribes "lacked such power." 57

The distinction between the exercise of delegated federal authority and the exercise of inherent tribal authority is significant. While Congress may place limitations and conditions on the exercise of inherent authority, neither Congress nor the Constitution is the source of inherent authority. There are realms of tribal self-government, presumably, into which Congress would not intrude and that fall outside the regulation of the Constitution. ${ }^{58}$ Delegated

52. Id. at 194-95 (the case against defendant Belgarde was still pending when the Supreme Court granted certiorari in Oliphant).

53. Oliphant v. Schlie, 544 F.2d 1007, 1009 (9th Cir. 1976), rev'd sub nom. Oliphant, 435 U.S. 191.

54. Oliphant, 435 U.S. at 212.

55. Id. at 208-09.

56. Alex Tallchief Skibine, The Court's Use of the Implicit Divestiture Doctrine to Implement Its Imperfect Notion of Federalism in Indian Country, 36 TULSA L. J. 267, 270 (2000); Deloria \& Newton, supra note 21, at 70-72.

57. Deloria \& Newton, supra note 21 , at 70-72.

58. Philip P. Frickey, Congressional Intent, Practical Reasoning, and the Dynamic Nature of Federal Indian Law, 78 CALIF. L. REV. 1137, 1139 (1990) ("At first glance, the power of Congress in federal Indian law appears virtually 
authority, on the other hand, has its roots in the Constitution and is an assignment of federal power to tribes. ${ }^{59}$ Moreover, when tribes exercise delegated federal authority, rather than inherent tribal authority, they are bound by constitutional constraints on federal power. ${ }^{60}$ Thus, for example, a tribe exercising delegated federal criminal power would be required to comply with Fifth Amendment grand jury requirements, even though tribal courts may be constituted in ways that make such compliance difficult, if not impossible. ${ }^{61}$

For many, the implicit divestiture theory is ill-founded because it rests upon a basic mistrust of tribal institutions. ${ }^{62}$ To support its conclusion of implicit divestiture in Oliphant, the Court cited the "great solicitude" of the United States to protect its citizens against "unwarranted intrusions on their personal liberty." 63 Presumably, the Court believed that tribal justice systems created an unacceptable potential for unwarranted intrusions on the personal liberty of non-Indians brought before them; for the Court, this concern outweighed the sovereignty interest of the tribe in preserving public order. ${ }^{64}$ In particular, the Court was reluctant to expose nonIndians to tribal criminal jurisdiction because it viewed tribes as an extra-constitutional political system in which nonIndians do not participate and which may include "foreign" customs and traditions. ${ }^{65}$

absolute. The Supreme Court has repeatedly said that Congress has plenary power in Indian affairs, and the Court has never struck down a federal statute directly regulating tribes on the ground that Congress exceeded its authority to govern Indian affairs.").

59. COHEN, supra note $44, \S 4.03[3]$, at 246 ("The Supreme Court has confirmed Congress's constitutional authority both to delegate federal power to tribes and to affirm inherent tribal power.").

60. Id. $\S 4.03[2]$, at 243-44.

61. I do not argue that Congress cannot or should not delegate federal authority, but rather, when it chooses instead to expressly recognize and affirm inherent tribal authority, the Court should defer to that Congressional judgment. See Alex Tallchief Skibine, Duro v. Reina and the Legislation That Overturned It: A Power Play of Constitutional Dimensions, 66 S. CAL. L. REV. 767, 804 (1993).

62. See, e.g., Robert A. Williams, Jr. The Algebra of Federal Indian Law: The Hard Trial of Decolonizing and Americanizing the White Man's Indian Jurisprudence, 1986 WIS. L. REV. 219, 267-75 n.174 (1986).

63. Oliphant v. Suquamish Indian Tribe, 435 U.S. 191, 210 (1978)

64. See id.; see also id. at 212 (Marshall, J., dissenting) (disagreeing with the majority's rejection of the tribe's right to "preserve order on the reservation" (quoting Oliphant v. Schlie, 544 F.2d 1007, 1009 (9th Cir. 1976))).

65. See Oliphant, 435 U.S. at 210 ("By submitting to the overriding sovereignty of the United States, Indian tribes therefore necessarily [gave] up 
In a similar illustration of the Court's view of the competence of tribal systems, the Court held in Duro v. Reina that tribes had also been impliedly divested of inherent authority to exercise criminal jurisdiction over members of other Indian tribes ("non-member Indians"). ${ }^{66}$ Albert Duro, a member of the Torres-Martinez Band of Cahuilla Mission Indians, allegedly shot and killed a teenage boy on the Salt River Reservation of the Salt River Pima-Maricopa Tribe in Arizona in 1984.67 Although Duro was charged in federal district court with murder under the Major Crimes Act, the charges were dismissed on motion of the U.S. Attorney. ${ }^{68}$ Duro was later criminally charged by the Salt River Pima-Maricopa Tribe with illegally firing a weapon on the reservation. ${ }^{69} \mathrm{He}$ challenged the criminal jurisdiction of the tribal court because he was not a member of the prosecuting tribe. ${ }^{70}$ Extending Oliphant, the Supreme Court in Duro expressed a "hesita[nce] to adopt a view of tribal sovereignty" that would subject nonmember Indians, as citizens of the United States, to trial by "political bodies that do not include them," i.e., tribal governments in which they are not political participants. ${ }^{71}$

The Court relied on Oliphant and other decisions to reason in Duro that "[i]n the area of criminal enforcement . . . tribal power does not extend beyond internal relations among

their power to try non-Indian citizens of the United States except in a manner acceptable to Congress. This principle would have been obvious a century ago when most Indian tribes were characterized by a "want of fixed laws [and] of competent tribunals of justice.") (second alteration in original).

66. See 495 U.S. 676, 688 (1990).

67. Id. at 679 .

68. Id. at 680 . The Major Crimes Act, 18 U.S.C. $§ 1153$ (1885), was originally passed in 1885 to ensure federal jurisdiction over murder, manslaughter, assault with intent to commit murder, arson, burglary, larceny, and rape where the crimes are committed by Indians against Indians in Indian country.

69. Id. at 681 .

70. Id. at 681-82. Tribal criminal jurisdiction is generally limited to misdemeanor jurisdiction by the Indian Civil Rights Act (ICRA), 25 U.S.C. $\S \S$ 1301-1303 (2012). Additionally, confinement as a form of punishment is limited; at the time of Duro's charge, the maximum penalty for tribal criminal penalties was six months' imprisonment and a $\$ 500$ fine. Duro, 495 U.S. 676, 681 (1990). Those maximums were subsequently increased in 1986 to one-year imprisonment and a $\$ 5,000$ fine. $I d$. at $681 \mathrm{n} .2$. However, in 2010, the ICRA was amended by the Tribal Law and Order Act of 2010, Pub. L. No. 111-211, 124 Stat. 2261 (codified as amended in scattered sections of 25 U.S.C.), to allow tribes complying with certain conditions to exercise enhanced sentencing authority to impose penalties up to three years and a $\$ 15,000$ fine. 25 U.S.C. $\$ 1302(b)$ (2012).

71. Duro, 495 U.S. at 693. 
members." 22 Identifying the same concerns that motivated the decision in Oliphant, the Court observed that Albert Duro could not vote, hold office, or serve on a jury of the Salt River Pima-Maricopa Tribe. ${ }^{73}$ The Court wrote that, "[f]or purposes of criminal jurisdiction, petitioner's relations with this Tribe are the same as the non-Indians in Oliphant. We hold that the Tribe's powers over him are subject to the same limitations."74 The Court's extension of Oliphant in Duro further hamstrung tribal criminal justice systems by stripping significant powers of public safety and law enforcement from tribes and leaving tribal members without effective recourse in responding to crimes in their communities.

While Congress has never taken any serious steps to modify the Court's holding in Oliphant until its consideration of the tribal jurisdiction provisions in VAWA, Congress did respond to the Duro decision..$^{75}$ In 1990 , Congress enacted what is called "the Duro fix," amending the Indian Civil Rights Act to define tribal "powers of self-government" to include criminal jurisdiction over "all Indians."76 Significantly, Congress did not purport to delegate a federal power to tribes to exercise criminal jurisdiction over non-member Indians. 77 Instead, Congress chose to "recognize[ ]" and "affirm[ ]" the inherent authority of tribes to exercise the jurisdiction at issue. ${ }^{78}$

In United States v. Lara, the Supreme Court scrutinized Congress's action recognizing and affirming inherent authority over non-member Indians. ${ }^{79}$ Billy Jo Lara was a member of the Turtle Mountain Band of Chippewa Indians married to a member of the Spirit Lake Sioux Tribe in North Dakota ${ }^{80}$ Lara lived on the Spirit Lake Reservation with his wife and children,

72. Id. at 688 .

73. Id. at 677 .

74. Id. at 688 .

75. Department of Defense Appropriations Act, 1991, Pub. L. No. 101-511, § 8077(b), (c), 104 Stat. 1856 (1990); 25 U.S.C. $\$ \S 1301(2), 1301(4)$ (2012) (defining "Indian" as "any person who would be subject to the jurisdiction of the United States as an Indian" under 18 U.S.C. $\$ 1153$ ).

76. See $\S 8077(\mathrm{~b})$, (c); COHEN, supra note $44, \S 4.03$ [3], at 247 (discussing "the so-called Duro-fix legislation"); 25 U.S.C. $\$ \S 1301(2), 1301(4)(2012)$.

77. 25 U.S.C. $\$ \S 1301(2), 1301(4)$.

78. Congress defined the "powers of self-government" to mean "the inherent power of Indian tribes, hereby recognized and affirmed, to exercise criminal jurisdiction over all Indians." Id. \$1301(2) (emphasis added).

79. 541 U.S. $193,196(2004)$.

80. Id. 
where he was accused of repeated misconduct. ${ }^{81}$ The Spirit Lake Tribe ordered Lara banished from the reservation. ${ }^{82}$ Lara violated the exclusion order and assaulted a federal officer. ${ }^{83}$ He was convicted in the Spirit Lake tribal court for the tribal offense of "violence to a policeman" and was subsequently charged by federal prosecutors with assaulting a federal officer for the same incident. ${ }^{84}$

While Lara did not challenge the tribe's jurisdiction directly, he did challenge the federal prosecution as violating the Double Jeopardy Clause of the Constitution under the theory that the tribe was exercising delegated federal authority in asserting criminal jurisdiction over him as a non-member Indian. ${ }^{85}$ If Congress's Duro fix was merely a delegation of federal authority to tribes, then Lara had a case for double jeopardy in challenging the subsequent federal prosecution because the source of the prosecuting authority for both the tribe and the U.S. Attorney would have been federal power, emanating from the same sovereign. Related tribal and federal prosecutions arising from the same set of facts do not normally implicate the Double Jeopardy Clause because each sovereign political community exercises its own separate and concurrent authority, much like state and federal prosecutions for crimes arising out of the same incidents. ${ }^{86}$ Lara argued that Congress could not enlarge inherent tribal authority where the Supreme Court had found such authority to be divested. ${ }^{87}$ The nature of the jurisdiction asserted by the Spirit Lake Tribe over Lara turned on whether Congress could revise the Court's inherent tribal authority jurisprudence. ${ }^{88}$ If the Court's holding in Duro divesting tribes of criminal jurisdiction over non-member Indians rested on a determination that the Constitution itself required divesting the tribe of criminal jurisdiction over nonIndians, that holding would be out of reach of legislative modification.

The Court deferred to Congress and resolved the question in favor of congressional power over Indian affairs. The Lara

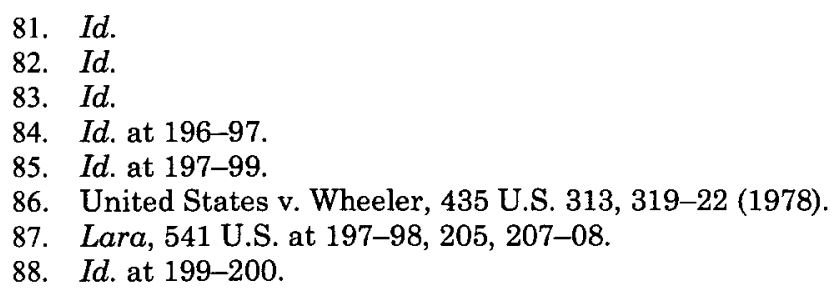


Court held that "the Constitution authorizes Congress to permit tribes, as an exercise of their inherent tribal authority, to prosecute non-member Indians." 89 But despite the holding favorable to the power of Congress over Indian affairs, Lara did not address the question of whether the Constitution authorizes Congress to permit tribes, as an exercise of their inherent tribal authority, to prosecute non-Indians. ${ }^{90}$

Indeed, the various opinions in Lara suggest that the Court is deeply divided about whether Congress could constitutionally define inherent tribal authority to include criminal jurisdiction over non-Indians. The concurring and dissenting opinions in Lara flagged potential constitutional concerns, not squarely presented in Lara, with subjecting nonIndians to tribal criminal jurisdiction and expressed at least some skepticism about Congress's authority to expand the bounds of inherent tribal authority beyond the Court's conception of what is necessary for tribal self-government. ${ }^{91}$

While the majority held that the power asserted by Congress to enact the Duro fix is anchored in the Constitution, ${ }^{92}$ the concurring and dissenting opinions revealed conflicting views of the scope of Congress's power. Justice Stevens' brief concurring opinion found "nothing exceptional" in recognizing the power of Congress to "relax restrictions on an ancient inherent tribal power" given that the "inherent sovereignty of Indian tribes has a historical basis that merits special mention."93 Justice Kennedy, concurring in the judgment, found the majority's rationale "most doubtful" because in his view, the case did not present the Constitutional question the Court answered about the reach of legislative authority; instead, Justice Kennedy believed the Court need only to conclude that the prosecution at issue did not violate double jeopardy. ${ }^{94}$ Justice Thomas, also concurring in the

89. Id. at 210 .

90. Id. at 205 ("Nor do we now consider the question whether the Constitution's Due Process or Equal Protection Clauses prohibit tribes from prosecuting a nonmember citizen of the United States.").

91. Id. at $210-31$.

92. Id. at 210 .

93. Id. at 210-11 (Stevens, J., concurring).

94. Id. at 211-13 (Kennedy, J., concurring).

[T] he first prosecution of Lara was not a delegated federal prosecution, and his double jeopardy argument must fail. That is all we need say to resolve this case. . . It is a most troubling proposition to say that 
judgment, wrote that he could not "agree with the Court... that the Constitution grants to Congress plenary power to calibrate the "metes and bounds of tribal sovereignty," and wrestled with whether the calibration of inherent tribal sovereignty is a matter for the executive, the judiciary, or the legislative. ${ }^{95}$ In dissent, Justice Souter argued that the Court's holding in Duro was "constitutional in nature" and he therefore rejected the effort of Congress to affirm the inherent tribal authority that the Court had found to be divested..$^{96}$ For Souter, only a delegation of federal authority could empower tribes to exercise the criminal jurisdiction at issue in Duro and Lara. ${ }^{97}$

Scholars, too, have continued to debate the proper roles of Congress and the courts in mapping inherent tribal authority, both civil and criminal, over non-Indians. Professor Alex Skibine argued that Duro represented the Court's unwarranted intrusion into Congress's plenary power over Indian affairs derived from the Indian Commerce Clause and the federal trust responsibility doctrine that places power over Indian affairs primarily with Congress. ${ }^{98}$ For Skibine, the "Court has arguably attempted to accomplish . . . an enormous constitutional power play aimed at stripping Congress of its traditional and exclusive role as the initial determiner of the relation between tribes and the United States and instead

Congress can relax the restrictions on inherent tribal sovereignty in a way that extends that sovereignty beyond [the] historical limits [identified in cases like United States v. Wheeler, 435 U.S. 313, 323 (1978), and Strate v. A-1 Contractors, 520 U.S. 438, 445-46 (1997)].

Id. at $211-12$.

95. Id. at 215-26 (Thomas, J., concurring).

96. Id. at 228-29 (Souter, J., dissenting).

97. Id. at 227, 231. Certainly, the composition of the Supreme Court has changed since the decision in Lara. It is not at all clear how the newly constituted Court will regard the Indian affairs power of Congress or the inherent sovereignty of tribes in the realm of criminal jurisdiction. It is clear that tribes face a daunting record from the Roberts Court: tribal interests have won only one of ten Indian law cases heard by the Roberts Court. Jefferson Keel and John Echohawk, Keeping a Close Eye on Michigan v. Bay Mills Indian Community, Natrve CONDITION, http://www.nativenewsnetwork.com/keeping-a-close-eye-on-michiganv-bay-mills-indian-community.html (last visited Nov. 10, 2013).

98. Skibine, supra note 61 , at $773,805-06$. See also COHEN, supra note 44 , § 5.05[1][a], at 418-19. But see Nell Jessop Newton, Federal Power Over Indians: Its Sources, Scope and Limitations, 132 U. PA. L. REV. 195 (1984) (questioning the validity of the Plenary Power Doctrine and arguing, pre-Duro, that the Court should apply intermediate scrutiny to certain enactments of Congress in Indian affairs and that tribes had been harmed by the Court's deference in Indian affairs). 
taking over that role itself." 99 Thus, Congress was entitled to assert the primacy of its Indian affairs power over inherent tribal authority in enacting the Duro fix, and the Supreme Court had sound reasons in Lara to acquiesce. ${ }^{100}$

The best reading of the judicial tea leaves suggests the Court is reluctant to recognize a congressional power affirming tribal criminal jurisdiction over non-Indians. However, Congress's reauthorization of VAWA indicates that Congress's view of its own power includes the power to affirm inherent tribal authority over some non-Indians in tailored circumstances and with a degree of federal regulation. ${ }^{101}$ This enactment puts the Court on a collision course with Congress, as VAWA demonstrates that at least some members of Congress view inherent tribal authority as encompassing a right of self-government broad enough to include the ability of tribes to punish criminal acts perpetrated by non-Indians against Indians within tribal territory. ${ }^{102}$ Congress seems to have determined that it does not share the Supreme Court's concern with the competence of tribal justice systems to deal fairly with such offenders or view the Constitution as an impediment to congressional affirmation of such authority. ${ }_{103}$ The recent legislative enactment affirming inherent tribal authority to prosecute non-Indian domestic violence offenders diverges from the Court's view of the competence and powers of

99. Skibine, supra note 61 , at 771 .

100. Id. at 805-06 ("The Duro legislation is constitutional because Congress, in passing the legislation, acted within the scope of its role as trustee for Indians and Indian tribes. Not only is the Duro legislation legal, but it was also the correct thing to do ... because Duro is an unprincipled decision representing a political viewpoint masquerading as a rule of constitutional law.... Duro is one of the latest and most ambitious attempts at this new kind of judicial activism, which not only aims to deny Indian tribes their status as viable domestic sovereigns under the Constitution but also attempts to usurp a role that rightfully belongs to Congress."). On the other hand, it could be argued that the Lara majority acquiesced to subjecting non-member Indians to criminal jurisdiction without the full panoply of due process rights normally afforded United States citizens within the territory of the United States. It gives no explanation for why this does not raise constitutional concerns.

101. 25 U.S.C.A. $\S \S 1301-1304$ (West 2013).

102. See, e.g., S. 47, 113th Cong. (2013) (Senate bill to reauthorize the Violence Against Women Act, including the tribal jurisdictional provisions); 159 CoNG. REC. S571, 579 (daily ed. Feb. 11, 2013) (statement of Senator Maria Cantwell) (supporting the tribal jurisdictional provisions); see also Newton, supra note 98, at 231.

103. See S. 47, 112th Cong. § 901-910 (2011). 
tribal courts as set forth in Oliphant.104 VAWA's tribal provisions affirming inherent tribal authority over non-Indians in the domestic violence context thus pits Congress's view of its power to say what inherent tribal authority means against the Supreme Court's view of Congress's Indian affairs power. ${ }^{105}$

The ongoing debate at the Supreme Court, in Congress, and among scholars about whether Congress or the courts has the ultimate authority to define the boundaries of tribal inherent authority demonstrates the clear need for a coherent framework to resolve this question. The next Part sets forth one suggested framework for doing so: the comparative institutional competency model derived from Garcia.

\section{THE COMPARATIVE INSTITUTIONAL COMPETENCY MODEL FOR DEFINING SOVEREIGNTY}

This Part derives a comparative institutional competency model from the federal-state sovereignty determination at

104. Violence Against Women Reauthorization Act of 2013, Pub. L. No. 113-4, 127 Stat. 54 (codified as amended at 42 U.S.C. \$ 904) ("Notwithstanding any other provision of law, in addition to all powers of self-government recognized and affirmed by sections 201 and 203 , the powers of self-government of a participating tribe include the inherent power of that tribe, which is hereby recognized and affirmed, to exercise special domestic violence criminal jurisdiction over all persons.") (emphasis added).

105. S. 47 was originally proposed to the 112 th Congress as S. 1925, a Department of Justice initiative that occurred after extensive consultation between the executive branch and tribal leaders about public safety. Letter from Jefferson Keel, President of the National Congress of American Indians, to Patrick J. Leahy, Chairman of the U.S. Senate Judiciary Committee, and Charles Grassley, U.S. Senate Judiciary Committee (July 25, 2011) (on file with author), available at http://tloa.ncai.org/documentlibrary/2011/07/Letter\%20to\%20SJC\% 20and\%20resolution.pdf. President Obama has endorsed the tribal provisions. EXeC. OfFice OF THE PRESident, STATEMENT OF ADMinistrative Policy: S. 47 VIOLENCE AGAINST WOMEN REAUTHORIZATION ACT OF 2013 (2013), http://www.whitehouse.gov//sites/default/files/omb/legislative/sap/113/saps47_ 20130204.pdf (last visited Nov. 12, 2013). In 2012, the Senate passed the VAWA reauthorization with the tribal provisions. S. 1925, 112th Cong. (as passed by Senate, Apr. 26, 2012). However, the House-passed version of the VAWA reauthorization did not include the tribal jurisdiction provisions. H. 4970, 112th Cong. (as passed by House, May 21, 2012). The discrepancy was seen as one of the key disputes holding up final action on the reauthorization of VAWA. In another attempt, the, Senate, again passed the VAWA reauthorization with the tribal provisions. Violence Against Women Reauthorization Act of 2013, S. 47, 113th Cong. (as passed by Senate, Feb. 11, 2013). On February 28, 2013, the House passed the Senate version of the VAWA, keeping the tribal jurisdiction provisions. Parker, supra note 14. 
issue in Garcia $v$. San Antonio Metropolitan Transit Authority 106 and from scholars in the field of comparative institutional competency, and argues for its application to questions of inherent tribal authority. Part II.A describes the Garcia model and explains why its treatment of traditional governmental functions and inviolable state sovereignty may illuminate the role of the Court on questions of tribal sovereignty. Part II.B applies the model to argue that the Court should defer to Congress's determinations about the proper scope and limits of tribal sovereignty.

\section{A. The Garcia Analog}

In Garcia, the Supreme Court considered the continued vitality of its attempts, begun in National League of Cities, 107 to craft judicial protection for a core of inviolable state sovereignty beyond the reach of federal regulation. ${ }^{108}$ At base the question posed in Garcia was whether the responsibility to protect state sovereignty - and the concomitant responsibility to determine whether some state powers are so fundamental to the functioning of state government that they should be immune from federal interference-rested with the courts or Congress. 109 To answer this question, the Garcia majority analyzed indicia of the comparative institutional competencies of the two branches of government in making the determinations about the necessary scope and limits of state sovereignty. ${ }^{110}$ The jurisprudence of the political question

106. 469 U.S. 528, 540-43 (1985).

107. Nat'l League of Cities v. Usery, 426 U.S. 833 (1976), overruled by Garcia, 469 U.S. 528.

108. The specific question at issue in Garcia was whether Congress could impose the minimum wage and overtime pay requirements of the Fair Labor Standards Act on state and local governments in their capacity as public employers. Garcia, 469 U.S. at 530-32. See Nat'l League of Cities, 426 U.S. at 852.

109. See Garcia, 469 U.S. at 547-58 (explaining that the approach of National League of Cities attempted "to defin[e] the limits of Congress's authority to regulate the States under the Commerce Clause" by "identif[ying] certain elements of political sovereignty that are deemed essential to the States' 'separate and independent existence" and noting that "[t]he point of the inquiry ... has remained to single out particular features of a State's internal governance that are deemed to be intrinsic parts of state sovereignty") (internal citation omitted).

110. Id. at 547-55; see also Rachel E. Barkow, More Supreme Than Court? The Fall of the Political Question Doctrine and the Rise of Judicial Supremacy, 102 COLUM. L. REV. 237, 254-55 (2002); Robert N. Clinton, The Rights of Indigenous Peoples as Collective Group Rights, 32 ARIZ. L. REV. 739, 744, 746 (1990) (noting 
doctrine and the literature of comparative institutional competence also suggest important factors to be weighed in determining the comparative competence of branches to make particular decisions. 11 Together with the lessons of Garcia, these additional indicia of comparative competencies include the relevant grants of constitutional power over the issues; the ability of the judiciary to develop consistent, workable standards to govern the determination; the role of political accountability in determining the appropriate respect due to competing sovereigns; the ability to tailor solutions and respond flexibly to changing circumstances; the control over resource allocation questions that may factor into policy determinations; and the subject matter expertise of the branch involved. ${ }^{112}$

This comparative institutional competency model developed in Garcia provides a compelling framework for analyzing whether the courts or Congress should serve as the final arbiter of inherent tribal authority. As this Part I.A demonstrates, the definition of "inherent tribal sovereignty"like the definition of "traditional state sovereignty," at issue in Garcia-requires the reconciliation of the needs and prerogatives of competing sovereigns, both of whom share-at least to some extent-authority over the same people and territory. Likewise, both inquiries require the decision-maker to determine which governmental powers are so fundamental

that, in Garcia, the Court determined that balancing of group rights against national interests "was best accomplished by the politically elected branches of government rather than the judiciary").

111. See, e.g., Baker v. Carr, 369 U.S. 186, 216-18 (1962) (surveying the kinds of matters which prompt a political question inquiry into justiciability, observing that:

Prominent on the surface of any case held to involve a political question is found a textually demonstrable constitutional commitment of the issue to a coordinate political department; or a lack of judicially discoverable and manageable standards for resolving it; or the impossibility of deciding without an initial policy determination of a kind clearly for nonjudicial discretion; or the impossibility of a court's undertaking independent resolution without expressing lack of respect due coordinate branches of government; or an unusual need for unquestioning adherence to a political decision already made; or the potentiality of embarrassment from multifarious pronouncements by various departments on one question.

112. Id.; see also Edward A. Hartnett, Modest Hope for a Modest Roberts Court: Deference, Facial Challenges, and the Comparative Competence of Courts, 59 SMU L. REV. 1735 (2006); Garcia, 469 U.S. at 547-55. 
to the functioning of a sovereign entity that, without them, the entity ceases to be sovereign in any meaningful sense. Similarly, both inquiries require the decision-maker to determine what aspects of sovereignty the entity can continue to exercise, consistent with the arguably greater sovereignty of the United States. 113 These questions are particularly difficult because they cannot be answered merely by reference to either historical or theoretical understandings of sovereignty itselfeven if the inherent characteristics of sovereignty could be clearly identified-as the subordinate entities in question have surrendered at least some of their sovereignty as part of the constitutional plan. ${ }^{114}$

When these types of sensitive and knotty questions of sovereignty are at stake, the comparative institutional competence of the respective branches of government ought to be the driving force in allocating authority to define the contours of this sovereignty. When sovereignty is at issue and the question is who decides who should decide, the Court suggests we look at the special competencies of the branches in determining to whom that decisional authority might be assigned. ${ }^{115}$ This approach ensures a full consideration of the

113. Garcia, 469 U.S. at 549 (arguing that while "States unquestionably do 'retai[n] a significant measure of sovereign authority.' ... [they do so] . . . 'only to the extent that the Constitution has not divested them of their original powers and transferred those powers to the Federal Government") (citations omitted).

114. Id. at 548 (expressing "doubt that courts ultimately can identify principled constitutional limitations on the scope of Congress's Commerce Clause powers over the States merely by relying on a priori definitions of state sovereignty" because "the sovereignty of the States is limited by the Constitution itself").

115. In other contexts, the Supreme Court has likewise been hesitant to decide questions that would require the Court to make fundamental determinations about the nature of sovereignty. For example, in Luther v. Borden, the Court held non-justiciable a challenge brought under Article IV, Section 4 of the Constitution (the "Guaranty Clause") that would have necessitated a court decision as to which of two competing governments in Rhode Island was the legitimate government. 48 U.S. 1, 39-41 (1849). The Guaranty Clause provides that "[t]he United States shall guarantee to every State in this Union a Republican Form of Government, and shall protect each of them from Invasion; and on Application of the Legislature, or of the Executive (when the Legislature cannot be convened) against domestic Violence." U.S. CoNST. art. IV, § 4 . In a later case, the Supreme Court also held non-justiciable a Guaranty Clause challenge to Oregon's adoption of procedures for referendums and initiatives, which would allow voters to both propose laws and override laws passed by the state's legislature. See Pac. States Tel. \& Tel. Co. v. Oregon, 223 U.S. 118, 149 (1912) ("It was long ago settled that the enforcement of this guarantee belong[s] to the political department."). See also Barkow, supra note 110, at 309-14. 
many factors that might affect the distribution of this definitional authority within a framework that effectively channels and disciplines the inquiry. ${ }^{116}$

Accordingly, this Article proposes that the Court consider this comparative institutional competency model in determining whether the power to define inherent tribal authority should rest with the courts or Congress. The following section, II.B, considers the comparative institutional competency of these branches to resolve these matters by evaluating a number of indicia of competence derived from Garcia, from political question jurisprudence, and from the literature of comparative institutional competency, particularly in the field of administrative law. This analysis suggests that it is Congress, rather than the Courts, that is best suited to make these complex and difficult policy decisions about the scope and content of inherent tribal authority that the United States will recognize. Throughout this analysis, the recently enacted tribal jurisdiction provisions of VAWA and other Congressional legislation serve as useful illustrative examples to demonstrate why the legislative branch is in the best position to tailor the exercise of inherent tribal authority over non-Indians in a way that balances the potential liberty interests of offenders with the interests of tribes in public order within their territories.

\section{B. Application of the Model: Indicia of Comparative Institutional Competency}

Garcia, in combination with political question jurisprudence ${ }^{117}$ and scholarly literature on comparative

116. Jason Mehta, The Development of Federal Professional Responsibility Rules: The Effect of Institutional Choice on Rule Outcomes, 6 CARDOZo PUB. L. POL'Y \& ETHICS J. 57, 72-73 (2007) (analyzing the relative competence of branches to develop professional responsibility rules for the legal profession and noting: "[T]his question of institutional competence is very much related to traditional 'separation of powers' philosophy. As a feature of our government, various institutions have been structured in different ways (with overlapping powers) to achieve different goals. . . The constitutional framers purposefully designed Congress [to] . . study, consider, and deliberate legislative problems."). See also Lon L. Fuller, The Forms and Limits of Adjudication, 92 HARV. L. REV. 353, 394-95 (1978) (expressing the view that some "polycentric" problems, or problems with such "complex repercussions" that "adjudication cannot encompass and take [them] into account," are ill-suited to the judicial capacity).

117. See, e.g., Garcia, 469 U.S. 546-57; Barkow, supra note 110, at 301-03. 
institutional competencies, ${ }^{118}$ suggests a number of important indicia by which comparative institutional competency should be assessed. These indicia include: the Constitution's delegation of authority to the respective branches; the susceptibility of the inquiry to judicially administrable standards; the need for political accountability for policy choices; the ability of the respective branches to appropriately tailor the necessary standards; the need for flexibility to respond to changed circumstances; the importance of resource allocation questions to the determination at issue; and the potential subject matter expertise of the decisionmaker. ${ }^{119}$

Application of these indicia of comparative competence to the definition of inherent tribal authority unequivocally demonstrates that Congress is the superior decisionmaker and that the Court should defer to Congress's determination of the boundaries of inherent tribal authority. First, the Constitution's grants of power to Congress over Indian affairs suggest that the Framers viewed Congress as the proper branch for management of the United States' Indian affairs power and the appropriate branch to decide questions about retained tribal sovereignty-questions that lie at the heart of virtually every policy decision about the United States' relationship with Indian tribes. Second, identifying what powers are inherent to tribal self-government is an inquiry not well-suited to judicial decision because this determination lacks judicially discoverable, objective criteria. Third, congressional determination of the limits of inherent tribal authority offers the democratic legitimacy of policy set by politically accountable actors. Fourth, Congress is the branch best able to tailor policies to reflect the varieties in tribal communities and capacities. Fifth, Congress has the flexibility to monitor and refine those policies when faced with changing circumstances. Sixth, the exercise of inherent tribal authority may depend on resource allocation decisions that are within the purview of Congress rather than the courts. Finally, Congress has superior access to subject matter expertise through hearings

118. See, e.g., Hartnett, supra note 112, at 1750-51; Emily Hammond Meazell, Presidential Control, Expertise, and the Deference Dilemma, 61 DUKE L.J. 1763 (2012); William N. Eskridge \& Lauren E. Baer, The Continuum of Deference: Supreme Court Treatment of Agency Statutory Interpretations from Chevron to Hamdan, 96 GEO. L.J. 1083 (2008).

119. See Garcia, 469 U.S. at 545-57. 
and studies that guide policy development more effectively than individualized cases and controversies before the courts.

\section{Constitutional Commitment of the Relevant Power}

The Court's decision in Garcia that the legislature-rather than the judiciary-is charged with determining whether federal regulation interferes with state sovereignty rested on its analysis of the scope of the powers the Constitution confers on Congress. ${ }^{120}$ The division of responsibilities assigned in the text and structure of the Constitution itself is, of course, a reflection of the Framers' assessment of which branch is most competent and trustworthy to exercise a particular power. Moreover, the competency of one branch of government to make a particular type of decision about sovereignty cannot be evaluated in the abstract, but must be judged instead by reference to the powers of other branches that might be brought to bear on the issue. Thus, the Garcia Court relied heavily on the broad scope of Congress's Commerce Clause authority ${ }^{121}$ and the structural, political checks on Congress's exercise of that power. ${ }^{122}$

A similar inquiry into the text and structure of Congress's power to regulate relations with the Indian tribes reveals a broad plenary power exercised by Congress over Indian affairs, underpinned primarily by the Indian Commerce Clause and Congress's trust relationship with the tribes (itself an outgrowth of Congress's treaty-ratification responsibilities). ${ }^{123}$ Under this plenary power doctrine, the exercise of tribes' inherent authority is subject to restriction by Congress as the policymaking branch of the superior sovereign.124 Given

120. Id. at 556 ("[T]he principal and basic limit on the federal commerce power is that inherent in all congressional action-the built-in restraints that our system provides through state participation in federal governmental action.").

121. See id. at 548 (noting that sections 8 and 10 of Article I effect a "sharp contraction of state sovereignty by authorizing Congress to exercise a wide range of legislative powers").

122. See id. at 550-51.

123. See supra Part II.A; see also Alex Tallchief Skibine, Integrating the Indian Trust Doctrine Into the Constitution, 39 TULSA L. REv. 247, 248-49 (2003).

124. See United States v. Kagama, 118 U.S. 375, 379-80 (1886). See e.g., Newton, supra note 98, at 212-15 (explaining the genesis of Congress's plenary power over Indian tribes); Alex Tallchief Skibine, Redefining the Status of Indian Tribes Within "Our Federalism": Beyond the Dependency Paradigm, 38 ConN. L. REV. 667, 673-75 (2006) (discussing the historical bases asserted for Congress's 
Congress's broad powers to remove inherent authority from tribes, it seems a modest proposal that Congress's Indian affairs powers are broad enough to include the power to recognize and affirm inherent tribal authority for the exercise of specific jurisdiction by tribes, without being constrained by the judicial branch's own conception of the proper limits of such tribal authority.

The United States has long asserted a broad and exclusive plenary power over Indian tribes. ${ }^{125}$ Scholars continue to debate the wisdom ${ }^{126}$ and extent ${ }^{127}$ of this plenary power; however, there is agreement that its exercise in the federal system rests primarily with Congress. ${ }^{128}$ The Indian affairs power of Congress derives from the text and structure of the Constitution. ${ }^{129}$ There are generally three sources of authority cited as underpinning congressional power over Indian affairs: the Indian Commerce Clause; ${ }^{130}$ the treaty ratification power; ${ }^{131}$ and, since Lara, the preconstitutional power over Indian affairs that is a "concomitant of nationality."132

Article I vests Congress with the power to regulate commerce with the Indian tribes, empowering Congress with broad legislative-regulatory authority. ${ }^{133}$ The Indian Commerce Clause provides authority for most legislation related to Indian affairs, and the authority is regarded as

plenary power over Indian tribes).

125. See United States v. Kagama, 118 U.S. 375, 379-80 (1886).

126. See, e.g., Robert N. Clinton, There Is No Federal Supremacy Clause for Indian Tribes, 34 ARIZ. ST. L.J. 113 (2002); Philip P. Frickey, Domesticating Federal Indian Law, 81 MINN. L. REV. 31 (1996); Alex Tallchief Skibine, Reconciling Federal and State Power Inside Indian Reservations with the Right of Tribal Self-Government and the Process of Self-Determination, 1995 UTAH L. REV. 1105 (1995).

127. See, e.g., Steven Paul McSloy, Back to the Future: Native American Sovereignty in the 21st Century, N.Y.U. REV. L. \& Soc. CHANGE 217 (1993); Robert G. Natelson, The Original Understanding of the Indian Commerce Clause, 85 DENV. U. L. REV. 201 (2007); Newton, supra note 98, at 198.

128. Newton, supra note 98 , at 228 .

129. Id. at 231.

130. Id. at 200-03.

131. Id. at $230-31$.

132. United States v. Lara, 541 U.S. 193, 201 (2004). See also Matthew L.M. Fletcher, Preconstitutional Federal Power, 82 TUL. L. REv. 509, 521-22 (2007) (explaining the three primary sources of Congress's plenary power over Indian tribes, including "preconstitutional federal authority"); Newton, supra note 98, at 207-11 (explaining the assertion of "extraconstitutional" sources of the federal government's plenary power over Indian tribes).

133. U.S. CoNST. art. I, § 8, cl. 3. 
plenary, but not absolute. ${ }^{134}$ While the Court has required legislation enacted pursuant to the interstate commerce clause to demonstrate a clear nexus to commerce, ${ }^{135}$ the Court has not required the same nexus in the regulation of Indian affairs. ${ }^{136}$ The Indian affairs power of Congress, derived at least in part from the Indian Commerce Clause, together with Congress's trust responsibility, is understood to legitimize congressional action in setting federal Indian policy and in enacting legislation carrying out that policy. ${ }^{137}$

In addition to the Indian Commerce Clause, the Senate's treaty-ratification power gives Congress significant involvement in the treaties negotiated by the executive. ${ }^{138}$ Congress has a duty to "carry out the obligations and execute the powers derived from these treaties." 139 This authority to effectuate the treaties confers upon Congress additional legislative and regulatory authority over tribes and a correlative responsibility to tribes. ${ }^{140}$ While the textual assignment of the power over Indian affairs is not absolute,

134. United States v. Alcea Band of Tillamooks, 329 U.S. 40, 54 (1946) ("The power of Congress over Indian affairs may be of a plenary nature; but it is not absolute."); COHEN, supra note $44, \S 5.02$, at 398-99.

135. See, e.g., United States v. Lopez, 514 U.S. 549, 561-62 (1995) (requiring a nexus between the target of legislation enacted under Congress's Commerce Clause authority and interstate commerce).

136. See United States v. John, 437 U.S. 634, 653 (1978) (citing the Indian Commerce Clause as a sufficient source of power for federal enforcement of the Major Crimes Act); Morton v. Mancari, 417 U.S. 535, 552 (1974) (explaining, among other constitutional and nonconstitutional provisions, the Indian Commerce Clause as the basis of Congress's plenary power over Indian tribes); see also United States v. Kagama, 118 U.S. 375, 378-380 (1886) (finding that reliance on the Indian Commerce Clause to authorize the Major Crimes Act, affirming the authority of the United States to prosecute major crimes by an Indian against an Indian in Indian country, required "a very strained construction of [the Indian Commerce] [C]lause").

137. See Lara, 541 U.S. at 200.

138. As with treaties with foreign powers, treaties with Indian tribes are the supreme law of the land, including those treaties ratified pursuant to the Articles of Confederation. Worcester v. Georgia, 31 U.S. 515, 559 (1832) (discussing Congress's "powers of war and peace; of making treaties, and of regulating commerce with foreign nations, and among the several states, and with the Indian tribes. These powers comprehend all that is required for the regulation of our intercourse with the Indians.").

139. COHEN, supra note 44 , at 91 .

140. See Worcester, 31 U.S. at 559; see also Pino v. United States, 38 Ct. Cl. 64, 68 (1903) (observing that treaties are not unilateral, but impose obligations on both parties). 
this "textual anchor"141 strengthens the prudential considerations in favor of congressional power to set the boundaries of inherent tribal authority.

In addition to the relatively clear constitutional sources of Congress's power, in Lara, Justice Breyer explored the source and reach of Congress's Indian affairs power to suggest the possibility of an additional, preconstitutional (read: inherent) power over Indian affairs akin to a foreign affairs power. ${ }^{142}$ This power to deal with the indigenous tribes, he said, though not enumerated, may be inherent to federal sovereignty as a "concomitant of nationality."143

In 1885, Congress passed the Major Crimes Act, placing seven major crimes under exclusive federal jurisdiction when committed by Indians in Indian country and removing from tribes what had been their own exclusive jurisdiction to punish crimes by Indians against Indians within tribal territories. ${ }^{144}$ Individual Indians subsequently charged under the Act challenged the authority of Congress to take this step in United States $v$. Kagama. 145 The United States asserted that the Indian Commerce Clause authorized the action, but the Court disagreed.146 The Court upheld the constitutionality of Congress's enactment of the Major Crimes Act pursuant to a theory of the exclusivity of the sovereign relationship of the United States with Indian tribes (vis-à-vis the states), as well as the federal power arising from the so-called guardian-ward

141. See Barkow, supra note 110, at 255 (noting that the Luther Court "relied on a grant of authority to Congress in the Guarantee Clause, as well as the practical difficulties of deciding whether a particular state government was 'republican,' to conclude that the interpretation of the Guarantee Clause rests with Congress. There was, then, a textual anchor to the prudential analysis. The Guarantee Clause states that the 'United States shall guarantee to every State in this Union a Republican Form of Government,' and the Court interpreted 'United States' to mean 'Congress.") (citations omitted) (emphasis added).

142. Lara, 541 U.S. at 201.

143. Id. Professor Fletcher suggests this theoretical exploration in Lara was meant to respond to Justice Thomas's skepticism, in his concurrence in Lara, of the plenary power doctrine as lacking a constitutional foundation. Fletcher, supra note 132 , at 523 .

144. United States v. Kagama, 118 U.S. 375, 377-80 (1886) (holding that reliance on the Indian Commerce Clause to authorize the Major Crimes Act, affirming the authority of the United States to prosecute major crimes by an Indian against an Indian in Indian country, would require "a very strained construction of [the Indian Commerce] [C]lause").

145. See id. at $375-76$.

146. Id. at $378-80$. 
relationship itself and the "duty of protection" associated with that guardianship obligation. ${ }^{147}$ Dean Newton explains the Court's Kagama holding as relying in part on the "inherent" power of Congress over Indian affairs because neither the Indian commerce power nor the treaty power could be used:

[T] he Court required a direct nexus with commerce to sustain federal laws regulating interstate and Indian commerce. . . . Acknowledging that no existing constitutional provision granted Congress this right to govern Indian affairs, the Court found it to be inherent . . . by analogy to early decisions regarding the power to regulate activities within the territories. ${ }^{148}$

Professor Fletcher and others have explored Justice Breyer's discussion of preconstitutional power as a concomitant of national sovereignty and others as part of the theoretical foundation for Congress's exercise of plenary power over Indian affairs. $^{149}$ In a foundational case of federal Indian jurisprudence, Justice Marshall said of Congress's Indian affairs powers that they "comprehend all that is required for the regulation of our intercourse with the Indians. They are not limited by any restrictions on their free actions. The shackles imposed on this power, in the confederation, are discarded." 150 Although the plenary power doctrine rightfully has its critics, ${ }^{151}$ it has been relied on by all three branches and by tribes to legitimize congressional action involving Indians, and has undergirded the broad policy formulations represented by Title 25 of the UNITED STATES Code since the beginning of

147. Id. at 383-85. See also Cherokee Nation v. Georgia, 30 U.S. 1, 17 (1831) ("[Tribal] relations to the United States resemble that of a ward to his guardian.").

148. Nell Jessup Newton, Federal Power Over Indians: Its Sources, Scope, and Limitations, 132 U. PA. L. REv. 195, 21.3-14 (1984) (citation omitted). See also 18 U.S.C. $§ 1153$ (2012).

149. Fletcher, supra note 132, at 509. Justice Breyer's observation stems from a 1938 decision where Justice Sutherland wrote that "the investment of the federal government with the powers of external sovereignty did not depend upon the affirmative grants of the Constitution . . . [but] would have vested in the federal government as necessary concomitants of nationality." United States v. Curtiss-Wright Export Corp., 299 U.S. 304, 318 (1936). See generally Charles A. Lofgren, United States v. Curtiss-Wright Export Corporation: An Historical Reassessment, 83 YALE L.J. 1 (1973) (analyzing Justice Sutherland's statement).

150. Worcester v. Georgia, 31 U.S. 515, 559 (1832).

151. See sources cited supra note 98. 
the United States. ${ }^{152}$

The combined effect of constitutional provisions like the Indian Commerce Clause and the other legislative and treatyratifying (and abrogating) powers of Congress is an Indian affairs power that is described at common law as "plenary" and as giving rise to a federal-tribal trust relationship. ${ }^{153}$ Congress is the principal trustee for Indian tribes. In describing the breadth of congressional power in Indian affairs, including the power to regulate tribal sovereignty, the Supreme Court said in Santa Clara Pueblo v. Martinez that:

As separate sovereigns pre-existing the Constitution, tribes have historically been regarded as unconstrained by those constitutional provisions framed specifically as limitations on federal or state authority. Thus ... this Court held that the Fifth Amendment did not "operat[e] upon" the "powers of local self-government enjoyed" by the tribes. . . . $[\mathrm{H}]$ owever, Congress has plenary authority to limit, modify or eliminate the powers of local self-government which the tribes otherwise possess. ${ }^{154}$

Indeed, the power of Congress over tribal sovereignty is so expansive that Congress has acted in the past to withdraw recognition from individual tribes and thus to annihilate their

152. See, e.g., Matthew L.M. Fletcher, The Supreme Court's Indian Problem, 59 HASTINGS L. J. 579, 615 (2008). There may be an important parallel in the Foreign Affairs Power, both in the source of the power as a concomitant of national sovereignty and in the allocation of power between the branches of the sovereign. Like the Foreign Affairs power, the Indian affairs power to deal with tribes is similarly an exclusively federal power, and all players similarly begin with the assumption that the power exists. See Linda Champlin \& Alan Schwarz, Political Question Doctrine and Allocation of the Foreign Affairs Power, 13 HOFSTRA L. REV. 215, 215 (1985) (observing that it "is generally agreed, that the United States, as a sovereign, has the full panoply of foreign relations power possessed by all sovereigns. Whether this full blooded power is implied or 'emergent' from the scant constitutional text, or is extra-constitutional in origin ... all players begin with the assumption that the power exists.") (citation omitted).

153. Fletcher, supra note 132, at 521-22 (explaining three primary sources of Congress's plenary power over Indian affairs). See also Lone Wolf v. Hitchcock, 187 U.S. 553, 565-67 (1903) (holding that Congress possesses a "paramount power" over Indian affairs "by reason of its exercise of guardianship over their interests" and that the "power exists to abrogate the provisions of an Indian treaty").

154. Santa Clara Pueblo v. Martinez, 436 U.S. 49, 56 (1978) (citations omitted). 
sovereignty and political existence entirely. ${ }^{155}$

These broad constitutional grants of power to Congress to regulate Indian affairs, especially when combined with any preconstitutional power Congress retained, suggest that the Framers viewed Congress, rather than the Courts, as the proper locus of decision-making authority about the extent of inherent tribal authority that tribes may continue to exercise. Additionally, while court-made common law has played a significant role in federal Indian law, there is no corollary textual or structural argument for the Court to assert a policymaking power over Indian affairs. 156 Just as the Garcia Court found no constitutional mandate-in the Tenth Amendment or otherwise-for courts to define a core of inviolable state sovereignty, ${ }^{157}$ there is no constitutional grant of authority to courts to define the limits of tribal inherent authority. ${ }^{158}$

In National League of Cities, the Court attempted to define a core of essential state sovereignty in order to protect the state-sovereigns from undue intrusion by Congress. ${ }^{159}$ Significantly, less than ten years later, the Court abandoned the task after finding itself unable to develop meaningful, judicially-manageable standards for applying its own tests. ${ }^{160}$ Unlike the well-meaning but unworkable attempt to craft standards protective of state sovereignty in National League of

155. See Charles F. Wilkinson \& Eric R. Biggs, The Evolution of Termination Policy, 5 AM. INDIAN L. REV. 139, 149-50 (1977) (describing the federal policy terminating tribes to promote assimilation).

156. Many have argued, in fact, that the Court has intruded on Congress's role and has exceeded the proper scope of its own authority by acting as a policymaker in the realm of Indian affairs. See Frickey, supra note 34, at 8, 35 (criticizing the Court's "gradual, incremental displacement of the political process in Indian affairs with judicial ad hoc judgments"); Matthew L.M. Fletcher, The Supreme Court and Federal Indian Policy, 85 NEB. L. REV. 121, 131 (2006) (explaining Indian law as an exception to "the Court's reluctance to engage in explicit policymaking").

157. Garcia v. San Antonio Metro. Transit Auth., 469 U.S. 528, 551-52 (1985).

158. While there is much to criticize in Congress's execution of its trust responsibility to tribes, it would be ironic for the Court to find that the one constraint on Congress's broad, plenary Indian affairs power-a power relied on to the detriment of Indian people in much of American history-is on Congress's ability to affirm powers of tribal self-government.

159. Nat'l League of Cities v. Usery, 426 U.S. 833, 852 (1976) (holding that Congress has no ability "to directly displace the States' freedom to structure integral operations in areas of traditional governmental functions"), overruled by Garcia v. San Antonio Metro. Transit Auth., 469 U.S. 528 (1985).

160. See Garcia, 469 U.S. at 539-46. 
Cities, in the realm of tribal inherent authority, the Court has intervened to limit-rather than protect-the sovereignty of tribes with similarly chaotic results. ${ }^{161}$ Thus, for example, the Court has repeatedly limited inherent tribal sovereignty even as Congress, through proposals such as those in VAWA, has seen fit to expand tribal sovereignty. ${ }^{162}$

The Court's limitation on inherent tribal sovereignty over some non-Indian criminal defendants in Oliphant has now been met with the express assertion by Congress that such authority does exist in the limited circumstances identified in the VAWA reauthorization. ${ }^{163}$ The Court in Lara found congressional assertion of authority over the boundaries of inherent tribal authority to be within the constitutional power of Congress. ${ }^{164}$ It is not at all clear where the Court would now look to find a limitation on the power of Congress to set the bounds of inherent tribal authority in the text, structure, or inherent powers of Congress over Indian affairs without overruling Lara.

\section{Judicially Discoverable, Objective Standards}

In Garcia, the Court set aside the "traditional governmental functions" inquiry of National League of Cities because finding a consistent organizing principle that enabled courts to define "the scope of the governmental functions" was elusive. ${ }^{165}$ The resulting case-by-case search for "a workable

161. See Atkinson Trading Co. v. Shirley, 532 U.S. 645, 653 (2001) ("An Indian tribe's sovereign power to tax-whatever its derivation-reaches no further than tribal land."); Nevada v. Hicks, 533 U.S. 353, 358-59 (2001) (ruling that tribal ownership of land is not sufficient to assert tribal regulatory jurisdiction over nonmembers); Strate v. A-1 Contractors, 520 U.S. 438, 442 (1997) (holding that tribe did not have adjudicatory jurisdiction over a vehicle accident involving nonmembers on tribal land); Duro v. Reina, 495 U.S. 676, 685-86 (1990) (applying the implicit divestiture doctrine to tribal regulation of nonmember Indians); Montana v. United States, 450 U.S. 544, 564 (1981); Oliphant v. Suquamish Indian Tribe, 435 U.S. 191, 211 (1978) (holding that Indian tribes do not have criminal jurisdiction over non-Indians absent express delegation from Congress).

162. See Tribal Law and Order Act of 2010, Pub. L. No. 111-211, 124 Stat. 2258 (codified as amended in scattered sections of 25 U.S.C.). See also Violence Against Women Reauthorization Act of 2013, Pub. L. No. 113-4, Title IX, 127 Stat. 54 (codified as amended in scattered sections $42,25,22$, and 18 U.S.C.).

163. Violence Against Women Reauthorization Act of 2013, Title IX.

164. United States v. Lara, 541 U.S. 193, 210 (2004).

165. Garcia v. San Antonio Metro. Transit Auth., 469 U.S. 528, 539 (1985) (emphasis added). 
standard for determining whether a particular governmental function should be immune from federal regulation under the Commerce Clause" failed to yield a consistent, objective principle; the Court found "an inability to specify precisely what aspects of a governmental function made it necessary to the 'unimpaired existence' of the States."166 The Court also rejected an effort to look to a purely historical standard as providing an objective organizing principle for the traditional governmental function inquiry. ${ }^{167}$ The Court found that the historical standard "prevents a court from accommodating changes in the historical functions of States." 168 The Court found the objectivity of the standard to be "illusory," resulting in "line-drawing of the most arbitrary sort."169

The same lack of judicially discernible, objective standards may be said to affect the Court's current inherent tribal authority jurisprudence. Courts have developed an unworkable inquiry in seeking to set the limits of inherent tribal authority. They have said that tribes have been stripped of all "external" sovereignty powers, yet retain powers of internal sovereignty that have not been implicitly divested. 170 Powers related to "internal sovereignty" may be implicitly divested if the Court views them as "inconsistent with" tribes' diminished status as limited sovereigns." 171 In seeking to determine whether a tribe retains an inherent governmental power, the Court generally looks to whether the power is necessary to the right of Indians

\footnotetext{
166. Id. at $540-41$.

167. Id. at 539 .

168. Id. at 543 .

169. Id. at 544 .
}

170. See Oliphant v. Suquamish Indian Tribe, 435 U.S. 191, 208-10 (1978) (stating that "Indian tribes are prohibited from exercising both those [powers restricted by Congress] and those powers 'inconsistent with their status").

171. Montana v. United States, 450 U.S. 544, 564 (1981) ("[E]xercise of tribal power beyond what is necessary to protect tribal self-government or to control internal relations is inconsistent with the dependent status of the tribes, and so cannot survive without express congressional delegation."). See also Nevada v. Hicks, 533 U.S. 353, 358-59 (2001) (holding tribal ownership of land insufficient to assert tribal regulatory jurisdiction over nonmembers); South Dakota v. Bourland, 508 U.S. 679, 695 n.15 (1993) (reinforcing Montana); Duro v. Reina, 495 U.S. 676, 685-86 (1990) (applying the implicit divestiture doctrine to tribal regulation of nonmember Indians); United States v. Wheeler, 435 U.S. 313, 32225 (1978) ("[The tribes'] incorporation within the territory of the United States, and their acceptance of its protection, necessarily divested them of some aspects of the sovereignty which they had previously exercised."). 
"to make their own laws and be ruled by them." 172

The developments of the subjective internal-externalrelations inquiry and the necessary-to-self-government inquiry have direct parallels with the Commerce Clause inquiry deemed fatally flawed in Garcia. ${ }^{173}$ Moreover, as with the National League of Cities traditional-governmental-function inquiry, the tribal-inherent-sovereignty inquiry has led to evermore convoluted outcomes. 174 The inquiry relies on a subjective categorization of some powers as internal and others as external. Some "internal relations" powers seem self-evident enough: tribes have the power to establish tribal membership requirements consistent with their cultural and historical values; tribes can prescribe inheritance rules; tribes have the power to elect or appoint leaders and form governing councils; and tribes can regulate domestic relations among members. ${ }^{175}$ The exercise of self-government also may include the power to exclude persons from membership or territory. ${ }^{176}$ Conversely, some tribal powers seem fairly categorized as "external." 177 Tribes may not negotiate treaties or forge alliances with foreign powers. ${ }^{178}$ Tribes have also been restricted in the sale of aboriginal lands, given the overriding legal interest of the United States in excluding others from acquiring those lands. ${ }^{179}$

However, the proper categorization of many other powers of tribal self-governance is far less clear. ${ }^{180}$ The determination

172. Williams v. Lee, 358 U.S. 217,220 (1959).

173. Garcia, 469 U.S. at 550-52. There is of course a limit to the analogy here between the States and tribes. The Court in Garcia found structural protections for the changing interests of states inherent in federalism. Id. at 551. States' representative capacities within the federal government create inherent protections for states' interests in the federal political branches. Tribes do not enjoy the same structural protection for their interests.

174. See sources cited supra note 161.

175. See COHEN, supra note $44, \S 4.04$, at $260-62$.

176. See Merrion v. Jicarilla Apache Tribe, 455 U.S. 130, 144-45 (1982).

177. Alex Tallchief Skibine, Dualism and the Dialogic of Incorporation in Federal Indian Law, 119 HARV. L. REV. F. 28 (2005) (observing that Justice Kennedy, in Duro v. Reina, "relied on dicta from Wheeler to find that tribal control over non-Indians was part of 'external relations' and therefore the tribes had necessarily been divested of such power upon incorporation into the United States").

178. See Cherokee Nation v. Georgia, 30 U.S. 1, 14 (1831) (characterizing Indian tribes as "domestic dependent nations").

179. Johnson v. McIntosh, 21 U.S. 543, 589-91 (1823).

180. Other scholars have likewise recognized the Court's difficulty in developing clear, administrable standards in this realm. See Frickey, (Native) 
of whether to characterize exercises of tribal sovereignty as external or internal has been particularly challenging when a tribe has sought to punish nonmembers who have criminally assaulted tribal members on tribal territory. ${ }^{181}$ In this criminal jurisdiction context, Oliphant and Duro were premised on the Court's conception of tribal criminal jurisdiction over non-tribal members as an exercise in external relations, even though the crimes in both cases were committed on tribal territory against tribal members. ${ }^{182}$ Importantly, however, courts have not explained what is inherently "external" rather than "internal" about maintaining public order through appropriate tribal regulation and law enforcement on tribal territory. A state or locality arguably exercises such powers as "internal" powers inherent to its own limited and dependent sovereignty without compromising the external relations of the United States. Indeed, in some respects, it is difficult to imagine a regulatory power more critical to self-government and the power of tribes to ensure the wellbeing of their own people. Because of the lack of objective criteria, tribes have thus been circumscribed in the exercise of what one court called the "sine qua non" of selfgovernance: the right to preserve public order through criminal jurisdiction under the Court's arbitrary internal-external relations paradigm. ${ }^{183}$

The unworkability of the Court's current approach is even more apparent in the civil jurisdiction context. In the "pathmarking" case of Montana v. United States, the Court

American Exceptionalism in Federal Public Law, supra note 26, at 433 (describing the "incoherence" of federal Indian law); Frickey, Malaise of Federal Indian Law, supra note 34, at 9 (explaining that "a common lament is that federal Indian law is riddled with doctrinal inconsistency"); Frank Pommersheim, A Path Near the Clearing: An Essay on Constitutional Adjudication in Tribal Courts, 27 GONZ. L. REV. 393, 403 (1991) (noting the Court's 'bifurcated, if not fully schizophrenic, approach to tribal sovereignty"); Blake A. Watson, The Thrust and Parry of Federal Indian Law, 23 U. DAYTON L. REV. 437, 439 (1998) (noting that, in regard to the Court's Indian law precedents, "leading scholars have consistently remarked on the distressing degree to which the Court's statements and holdings may be counterpoised").

181. Duro v. Reina, 495 U.S. 676, 680 (1990); Oliphant v. Suquamish Indian Tribe, 435 U.S. 191, 194 (1978).

182. Duro, 495 U.S. at 678; Oliphant, 435 U.S. at 194.

183. Oliphant v. Schlie, 544 F.2d 1007, 1009 (9th Cir. 1976) ("Surely the power to preserve order on the reservation, when necessary by punishing those who violate tribal law, is a sine qua non of the sovereignty that the Suquamish [Tribe] originally possessed."), rev'd sub nom. Oliphant v. Suquamish Indian Tribe, 435 U.S. 191 (1978). 
found that the Crow Tribe did not have the inherent authority to regulate hunting and fishing activities by non-Indians on non-Indian owned land within the boundaries of the Crow Reservation. ${ }^{184}$ Relying in part on Oliphant's rejection of inherent authority over non-Indians for criminal jurisdiction purposes, the Montana Court announced a "general proposition that the inherent sovereign powers of an Indian tribe do not extend to the activities of nonmembers of the tribe."185 Although the Court added that "to be sure, Indian tribes retain inherent sovereign power to exercise some forms of civil jurisdiction over non-Indians on their reservations, even on non-Indian fee lands," it went on to find tribal power over nonmembers does not extend "beyond what is necessary to protect tribal self-government or to control internal relations." 186 The Court characterized the issue in Montana as "a narrow one."187 It looked to the Tribe's treaties with the United States to determine whether the treaties could support some authority of the Tribe to regulate the hunting and fishing of non-Indians on non-Indian owned fee land and found no such intent in the treaties. ${ }^{188}$ The Court suggested that tribal regulatory authority over non-Indian activities on Indian lands would be a different matter. ${ }^{189}$

The subsequent development of the Montana rule illustrates that what was clear to the Montana court about external and internal relations has been clouded in later application. Since its announcement, tribes, non-Indians, and courts have struggled to apply the Montana rule. ${ }^{190}$ The result

184. Strate v. A.1 Contractors, 520 U.S. 438, 445 (1997) (Montana is a "pathmarking" case); Montana v. United States, 450 U.S. 544 (1981). Because of the policies of Allotment and Assimilation, land ownership on many reservations is a patchwork of trust land held in trust by the federal government for tribes and individual Indians and fee lands held by both tribal members and non-Indians. S. REP. No. 112-265, at 9 (2012) (Conf. Rep.) .

185. Montana, 450 U.S. at 565 .

186. Id. at 564 .

187. Id. at $557-61$.

188. Id.

189. Throughout its opinion, the Montana Court repeatedly elevated the nonIndian fee ownership of the land in question. Id. For example, at the end of the opinion, the Court specifically noted that Montana's regulatory scheme did not infringe on the ability of the Tribe to regulate hunting and fishing on tribal land. See id. at 566-67.

190. See generally Strate v. A-1 Contractors, 520 U.S. 438, 446-47 (1997) (tribe did not have adjudicatory jurisdiction over a vehicle accident on tribal land); Nevada v. Hicks, 533 U.S. 353, 358-359 (2001) (tribal ownership of land is not 
has been a steady erosion of inherent tribal civil jurisdiction by judicial fiat. ${ }^{191}$ Under the Montana rule, courts begin with a presumption against tribal civil regulatory jurisdiction over non-Indians on non-Indian land within the boundaries of the reservation. ${ }^{192}$ But Montana also announced two exceptions to the general rule, where presumably tribal civil jurisdiction over non-Indians on non-Indian land might obtain: (1) people "who enter consensual relationships with the tribe or its members, through commercial dealing, contracts, leases, or other arrangements"; and (2) conduct of non-Indians that "threatens or has some direct effect on the political integrity, the economic security, or the health or welfare of the tribe."193 The Court found that the hunting and fishing activities of non-Indians on non-Indian land within the Crow reservation boundaries guaranteed by treaty did not represent the kind of consensual relation or threatening conduct the Montana test envisioned. 194

In a later case applying the Montana formulation of the internal and external relations test for inherent tribal authority, the Court minimized the role that the status of the land as non-Indian had played in Montana. ${ }^{195}$ In Strate v. A-1 Contractors, the tribal court of the Three Affiliated Tribes accepted jurisdiction over a civil claim by Gisela Fredericks, a non-Indian widow of a tribal member and the mother of five adult tribal members, who had lived on the reservation since she was a young girl. 196 She sued for serious injuries she sustained in an accident with the operator of a truck employed by A-1 Contractors. 197 The accident occurred on a strip of highway on land held in trust by the federal government for the benefit of the Tribes, or, in other words, tribal land. ${ }^{198}$ A-1 Contractors had a contract with the Tribes for the construction of a new tribal administration building. ${ }^{199}$

sufficient to assert tribal regulatory jurisdiction over nonmembers); Atkinson Trading Co. v. Shirley, 532 U.S. 645, 653 (2001) ("An Indian tribe's sovereign power to tax-whatever its derivation-reaches no further than tribal land.").

191. Id.

192. See, e.g., Strate, 520 U.S. at 446.

193. Montana, 450 U.S. at 565-66.

194. See id. at 566-67.

195. See Strate, 520 U.S. at 454.

196. Id. at 442-43.

197. Id.

198. Id.

199. Id. at 443 . 
The tribal court believed it had jurisdiction over the claim despite Montana because of several distinguishing factors: the jurisdiction was adjudicatory rather than regulatory, ${ }^{200}$ the locus of the activity giving rise to the suit was tribal rather than private, 201 and the defendant was employed by a contractor who had entered into a consensual relationship with the Tribes. ${ }^{202}$ Still, the Supreme Court held that jurisdiction over the suit was not "necessary to protect tribal selfgovernment" and that requiring A-1 Contractors to defend against the suit "in an unfamiliar court is not crucial to the 'political integrity, the economic security, or the health or welfare of the [Tribes]."203 For many commentators, the outcome in Strate was driven by a subjective mistrust of the competency of tribal judicial systems, rather than an objective application of the Montana rule and its exceptions. ${ }^{204}$

Given the opacity and arbitrariness of the judicially crafted standards in this realm, it is hardly surprising that Congress appears to have rejected this internal-external relations paradigm. Rather than relying on arbitrary divisions between external and internal powers, Congress has instead pursued a substantive legislative agenda of strengthening tribal capacity and enhancing tribal self-governance to include authority over people and territory. In 2010, Congress enacted the Tribal Law and Order Act (TLOA) in response to a growing crisis of public safety on reservations and the limited ability of tribes to respond. ${ }^{205}$ The Act included measures to strengthen tribal courts and to develop tribal justice systems. In particular, TLOA provided a tailored way for tribes to exercise enhanced criminal sentencing authority, signifying a move from Congress to empower rather than diminish tribal jurisdiction. ${ }^{206}$ Prior to TLOA, Congress placed a statutory cap of one year on the

\footnotetext{
200. Id. at 447.

201. Id. at 454 .

202. Id. at 457 .

203. Id. at 459 (citation omitted).

204. See Robert N. Clinton, Redressing the Legacy of Conquest: A Vision Quest for A Decolonized Federal Indian Law, 46 ARK. L. REV. 77, 141 (1993) (describing the "unwillingness to accept Indian tribal governance or regulation" as a result of "the distrust of tribal governance by non-Indians"); Jesse Sixkiller, Note, Procedural Fairness: Ensuring Tribal Civil Jurisdiction After Plains Commerce Bank, 26 ARIZ. J. INTL. \& COMP. L. 779, 802 (2009) (citing Strate and Plains Commerce Bank for the proposition that the Court mistrusts tribal governance).

205. Pub. L. No. 111-211, 124 Stat. 2261 (2010).

206. Id. §234.
} 
sentencing authority of tribes. ${ }^{207}$ In the new regime, Tribes that take specific steps to ensure due process protections (having law-trained judges, providing effective assistance of counsel to the accused, and publishing rules of procedure) may exercise enhanced sentencing authority of up to three years per offense. ${ }^{208}$ This measure illustrates both the desire of Congress to build the institution of the tribal judiciary and the willingness of Congress to ensure protection of the due process and liberty concerns of those who come under tribal criminal jurisdiction.

Similarly, the tribal jurisdiction provisions of VAWA amend the Indian Civil Rights Act's definition of the powers of self-government of tribes in clear language that avoids the pitfalls of the Court's ill-defined search for those powers that are necessary to self-government in the Court's inconsistent estimation. ${ }^{209}$ The new law clarifies that "the powers of selfgovernment of a participating tribe include the inherent power of that tribe, which is hereby recognized and affirmed to exercise special domestic violence jurisdiction over all persons." 210 The amendments represent Congress's express will and judgments regarding what powers are encompassed within the powers of self-government and further, what powers qualify as inherent powers of tribal authority.

The Court's failure to identify and apply objective, predictable standards in this field-or give adequate guidance to Congress and Tribes about the scope of their powers-is reason enough for the courts to stop second-guessing Congress's policy-making in this realm. The relationship between the federally-recognized tribes and the federal government is a government-to-government relationship and rests in large part on negotiated government-to-government agreements. The political question doctrine suggests that when the judiciary is presented with questions affecting the relationship with foreign powers, the "judicial department... follows the action of the political branch." 211 For the Court to strike down the tribal jurisdiction provisions enacted in VAWA

207. Id.

208. Id.

209. Violence Against Women Reauthorization Act of 2013, Pub. L. No. 113-4, 127 Stat. 54 (codified as amended in scattered sections $42,25,22$, and 18 U.S.C.).

210. Id. § 121 .

211. United States v. Lee, 106 U.S. 196, 209 (1882). 
would similarly represent an intrusion upon the legislature's prerogatives in managing Indian affairs.

\section{The Need for Political Accountability}

As Garcia suggests, a third important consideration for evaluating the comparative institutional competency of the courts and Congress is the extent to which the sensitive sovereignty questions are policy issues that ought to be resolved by politically accountable actors rather than insulated and unaccountable courts. ${ }^{212}$ The question of whether nonIndians may be subject to any tribal criminal process involves weighing constitutional and other legal and prudential values. Not only are the tribal rights at stake, but also the rights of potential defendants. The question presents a mix of policy, political, and legal questions and requires a balancing of majority-minority interests that ought to be made by politically accountable actors.

In administrative law, the desire to ensure that politically accountable actors make critical policy determinations is one justification for the courts' fundamental obligation to defer to the statutory interpretation of an agency. ${ }^{213}$ As Professor Paul Horwitz has argued, when courts defer to "other actors, courts open up a space for shared legal and constitutional interpretation by other actors who may be closer to the facts on

212. See Garcia v. San Antonio Metro. Transit Auth., 469 U.S. 528, 545-46 (1985) (rejecting the ability of "an unelected federal judiciary" to define the nature and extent of governmental functions by deciding "which state policies it favors and which ones it dislikes").

213. See Chevron, U.S.A., Inc. v. Nat'l Resources Def. Council, Inc., 467 U.S. 837, 866-67 (1984) (explaining that agencies are in a better position to resolve "competing views of the public interest" due to their indirect political accountability). In discussing the democratic legitimacy argument advanced in Chevron in support of court deference to agency interpretations of statutes where delegation of authority may be implicit, the authors note a three-prong rationale in favor of deference: (1) courts may not substitute their own interpretation of a statutory provision if the agency's interpretation is reasonable, (2) agencies may have experience and expert judgment necessary to reconcile conflicting policies, and (3) agencies have greater political accountability than courts because the executive is accountable. William N. Eskridge \& Lauren E. Baer, The Continuum of Deference: Supreme Court Treatment of Agency Statutory Interpretations from Chevron to Hamdan, 96 GEO. L.J. 1083, 1086 (2008). They note that where agencies, as politically accountable actors, then, "fill[ ] the statutory gap in a reasonable way, 'federal judges-who have no constituency-have a duty to respect legitimate policy choices made by those who do." Id. at 1087 (citing Cheuron, 467 U.S. at $865-66$ ). 
the ground. Thus, deference allows courts to bring responsiveness into the law by taking themselves out of the equation."214 Deference, of course, "is not the same thing as agreement."215 The divergence between the judicial and Congressional approaches to inherent tribal sovereignty over the last generation is a perfect illustration of the imperative to defer to politically accountable actors on sensitive decisions of sovereignty.

While Congress has signaled an interest in building tribal capacity, in recent decades courts have consistently diminished the scope of inherent tribal sovereignty. ${ }^{216}$ The focus of federal Indian policy as articulated by Congress, and indeed by the executive, has been toward enhanced tribal selfdetermination. ${ }^{217}$ Current federal Indian advocates describe a move toward a policy not just of self-determination but also of nation building, emphasizing the development of tribal institutions and tribal participation in the American polity. ${ }^{218}$ At the same time that Congress has pursued this agenda of strengthening tribes and tribal capacity, the Court has upended the traditional presumptions in favor of tribal authority without express divestiture and developed a theory of implicit divestiture. ${ }^{219}$ It thus appears, as some have charged,

214. Horwitz, supra note 25, at 1066.

215. Id. at 1075. Professor Paul Horwitz's explanation of deference as a prudential tool in decision-making defines deference as involving "a decisionmaker (D1) setting aside its own judgment and following the judgment of another decision-maker (D2) in circumstances in which the deferring decision-maker, D1, might have reached a different decision." Id. at 1072.

216. See generally Oliphant v. Suquamish Indian Tribe, 435 U.S. 191 (1978) (Indian tribes do not have criminal jurisdiction over non-Indians absent express delegation from Congress); Strate v. A-1 Contractors, 520 U.S. 438 (1997) (tribe did not have adjudicatory jurisdiction over a vehicle accident on tribal land); Nevada v. Hicks, 533 U.S. 353, 358-359 (2001) (tribal ownership of land is not sufficient to assert tribal regulatory jurisdiction over nonmembers); Atkinson Trading Co. v. Shirley, 532 U.S. 645, 653 (2001) ("An Indian tribe's sovereign power to tax-whatever its derivation-reaches no further than tribal land.").

217. See Pub. L. No. 93-638, 88 Stat. 2203 (1975) (codified as amended at 25 U.S.C. $\S 450-458$ ); Pub. L. No. 103-413, tit. III, 108 Stat. 4270 (1994) (codified at 25 U.S.C. § 450a, 458aa et seq.). See generally Robert A. Williams, Jr., The Algebra of Federal Indian Law: The Hard Trial of Decolonizing and Americanizing the White Man's Indian Jurisprudence, 1986 WIS. L. REV. 219 (1986).

218. See generally Matthew L.M. Fletcher, Tribal Membership and Indian Nationhood, 37 AM. INDIAN L. REV. 1, 15-17 (2012-2013).

219. See Brendale v. Confederated Tribes and Bands of Yakima Indian Nation, 492 U.S. 408, 451-52 (1989). 
that the Court has attempted to effect a change in federal Indian policy by judicial fiat that flies in the face of the traditional role of Congress as the politically accountable policymaker. 220

Thus, even as the tribes and the federal government have pursued an enhanced government-to-government relationship and the political branches have expressed repeated commitment to the continuing vitality of the federal-tribal trust relationship, the federal common law of inherent tribal authority has not kept up with-indeed, appears at odds with-this shift by the politically-accountable branches. Professor Frickey and others have observed that "the Court has gradually undertaken a broader role ... displacing the primary congressional responsibility for Indian affairs with a judicial attempt to address contemporary contextual dilemmas in federal Indian law on a case-by-case basis."221 Professor Frickey assesses the Court's performance in the policymaking role in federal Indian law as "quite poor[ ]" and summarizes the judicial intrusion as having:

produced incoherent doctrinal compromises, jettisoned the longstanding institutional understandings in the field in favor of an ill-defined judicial role, and destroyed practical incentives for congressional and negotiated solutions to the myriad of invariably differentiated local problems of tribal relations with states, local governments, and nonmembers. Rather than moving the field toward sounder structural, normative and practical moorings, the Court has left the law in a mess, done little to promise effective solutions to practical problems, and been more normatively concerned about undermining tribal authority to protect nonmembers than about promoting a viable framework for tribal flourishing in the twenty-first century. ${ }^{222}$

While there is much to criticize in Congress's approach to

220. See Frickey, Malaise of Federal Indian Law, supra note 34, at 8; Getches, supra note 12, at 1573 (arguing that, more recently, the Court has based its Indian law decisions on the basis of the "Justices' subjective notions of what the Indian jurisdictional situation ought to be"); Deloria \& Newton, supra note 21, at 72-73 (citing inconsistency between the Court's historical deference to congressional Indian law policy and its holding in Duro).

221. Frickey, Malaise of Federal Indian Law, supra note 34, at 8.

222. Id. 
tribal sovereignty, Congress is at least politically accountable for its missteps and has some incentive to correct them.

Our constitutional scheme is, of course, willing to tolerate departures from democratic norms of political accountability to ensure that minority rights are protected against majoritarian over-reaching. ${ }^{223} \mathrm{~A}$ primary role of the judiciary within the system of checks and balances is to serve as an apolitical, counter-majoritarian check to protect minority interests and curb legislative abuses. ${ }^{224}$ One terrible risk in emphasizing the legislative role in deciding questions of inherent tribal authority is the danger of subjecting the tribal population of minority interests to popular will. As the debate of the VAWA provisions demonstrated, tribes are vulnerable targets of prejudice and mistrust. Still, even if the question of the bounds of inherent tribal authority rests with the courts, the plenary power of Congress looms large.

In the inherent tribal authority context, however, the Court appears to have enacted its prejudices against the minority interests of tribes at a significant cost to tribal interests in public order. ${ }^{225}$ Whereas Congress must account for the way it strikes a balance of the competing interests at issue, the Article III tenure and salary protections for federal judges are designed to insulate them from exactly this kind of accountability for their decisions. ${ }^{226}$ Indeed, when Congress acts, it is politically accountable not only for the practical consequences of its legislation for non-Indians but also for its judgment about the constitutionality of its own authority to act

223. See, e.g., W. Va. State Bd. of Educ. v. Barnette, 319 U.S. 624, 638 (1943) ("The very purpose of a Bill of Rights was to withdraw certain subjects from the vicissitudes of political controversy, to place them beyond the reach of majorities."); see also Chambers v. Florida, 309 U.S. 227, 241 (1940) (Courts are "havens of refuge for those who might otherwise suffer because they are helpless, weak, outnumbered, or because they are nonconforming victims of prejudice and public excitement."); Michael J. Klarman, Rethinking the Civil Rights and Civil Liberties Revolutions, 82 VA. L. REV. 1, 67 (1996).

224. See The Federalist No. 78 (Alexander Hamilton) (describing the courts as "bulwarks of a limited Constitution against legislative encroachments").

225. See Getches, supra note 12, at 1573. One potential objection to this argument is that the minority rights to be protected are those of individual criminal defendants, rather than the rights of the tribes. However, non-Indians are not minorities in this country, and there is little reason to think that Congress will impinge too greatly on the rights of the majority of its non-Indian constituents to satisfy the interests of minority tribes.

226. See THE FEDERALIST No. 78, supra note 224 (describing the life tenure of judges as contributing to the "independent spirit" of judges). 
on the matter.

As between Congress and the Supreme Court, it is Congress that is the politically accountable branch charged with reconciling conflicting political choices and more likely to have the experience and expertise for resolving such conflicting interests. Such accountability enhances the legitimacy of the decision and makes it more likely that a politically acceptable resolution of those conflicting interests can be reached. Thus, if Congress acts rationally in setting the limits of inherent tribal authority, it is not for the Court to substitute its policy judgment.

The debate over the tribal jurisdiction provisions of VAWA provides a striking example of the difficult political choices made by the legislature in taking the step to affirm inherent tribal authority to exercise special domestic violence jurisdiction over non-Indians. ${ }^{227}$ The political constituencies and competing perspectives were able to debate the change, the anticipated consequences of the change, and the wisdom of the specific means used during multiple hearings and floor debates. The votes and views of the duly elected political representatives from each state, some with tribal constituencies and some without, were brought to bear on the ultimate decision of Congress to make the change to tribal jurisdiction.

\section{Tailoring Solutions to Balance Competing Interests}

Another of the important indicia of comparative institutional competency for making sensitive decisions about the scope and ambit of retained sovereignty is the ability to forge nuanced, closely tailored solutions that balance the interests of both the competing sovereigns and individual citizens. ${ }^{228}$ Congress is better situated than courts to weigh and consider the various interests of tribes, the federal government,

227. 159 CONG. REC. S571, 571-86 (daily ed. Feb. 11, 2013) (debating the Coburn Amendment seeking to strip the tribal jurisdiction amendments from the Senate bill reauthorizing the Violence Against Women Act); Parker, supra note 12; Weisman, supra note 14.

228. See Garcia v. San Antonio Metro. Transit Auth., 469 U.S. 528, 554 (1985) (observing that in the context of the statute at issue in Garcia, restraints on the political process require a "tailored" solution). 


\section{and individual citizens.}

The Article III power of the courts is not intended to forge tailored compromise. There is generally a winner and loser in the case or controversy at issue. In the matter of inherent tribal authority, the decisions and concerns of the Court implicate the interests of all 566 federally-recognized tribes, but are derived from the limited facts of the case at bar and may depend in some cases on the quality of advocacy available to the parties. Federally recognized tribes are widely varied in their levels of funding, infrastructure, institutions, populations, and interests. ${ }^{229}$ Courts are not well suited to account for this level of variety among tribes acting in their sovereign capacities. The Court in Oliphant announced a bright-line rule denying inherent criminal jurisdiction over non-Indians based in part on the fact that the Tribe provided no opportunity for non-Indians to serve on tribal juries. ${ }^{230}$ The holding, based on narrow facts, had consequences for all tribes without consideration of individual tribal variation in reservation demographics or opportunity for democratic participation.

Congress, however, can develop programs and policies that set minimum standards for tribal governments in the exercise of inherent authority over non-Indians. The tribal provisions of VAWA do just that. ${ }^{231}$ Rather than announce a bright-line rule applicable to all tribes regardless of capacity, the legislation requires tribes to meet certain criteria in order to exercise the special domestic violence jurisdiction the legislation affirms. ${ }^{232}$

229. See, e.g., Oliphant v. Suquamish Indian Tribe, 435 U.S. 191, 211-12 (1978) ("We recognize that some Indian tribal court systems have become increasingly sophisticated and resemble in many respects their state counterparts. We also acknowledge that with the passage of the Indian Civil Rights Act of 1968, which extends certain basic procedural rights to anyone tried in Indian tribal court, many of the dangers that might have accompanied the exercise by tribal courts of criminal jurisdiction over non-Indians only a few decades ago have disappeared. Finally, we are not unaware of the prevalence of non-Indian crime on today's reservations which the tribes forcefully argue requires the ability to try non-Indians. But these are considerations for Congress to weigh in deciding whether Indian tribes should finally be authorized to try nonIndians. They have little relevance to the principles which lead us to conclude that Indian tribes do not have inherent jurisdiction to try and to punish nonIndians.").

230. Id. at 193.

231. Violence Against Women Reauthorization Act of 2013, Pub. L. No. 113-4, 127 Stat. 54 (codified as amended in scattered sections $42,25,22$, and 18 U.S.C.) (VAWA of 2013 included Title IX-Safety for Indian Women).

232. Id. 
These safeguards strike a tailored balance between the rights of individuals brought before tribal courts and the strong interest of tribes in public safety and order. The legislation also provides for rights of appeal to enhance protection of nonIndian defendants. ${ }^{233}$ Under the legislation, "participating tribes" work with the Department of Justice to develop tribal capacity to assert this jurisdiction. ${ }^{234}$ The Department of Justice certification requires that tribes have adequate protection and transparent procedures in place to protect the procedural and substantive rights of individuals brought before the tribal court. 235 Under this model, Congress sets the standards governing the exercise of tribal authority, and tribes work with the executive to ensure that the standards are met; moreover, courts are given a reviewing role to ensure that the procedures are operating as anticipated. ${ }^{236}$ This tailored balancing accounts for the variety of circumstances among the federally recognized tribes in a way that court decisions cannot.

The difficulties of crafting coherent yet appropriately nuanced rules based on a case-by-case consideration of a limited judicial record are also illustrated by the quandary some justices believe the Supreme Court may have created in Lara itself. As discussed above, the Court in Lara deferred to the plenary power of Congress over Indian affairs and thus held that Congress could affirm inherent tribal authority to exercise criminal jurisdiction over non-member Indians. 237 Justice Kennedy, concurring in the judgment, cautioned that the Lara holding should be read narrowly and suggested that the holding exceeded the question presented. ${ }^{238}$ Indeed, Justice Kennedy's concurrence argued that the Court's formulation raised "difficult questions of constitutional dimension" regarding the competence of Congress to "subject American citizens to the authority of an extraconstitutional sovereign to which they had not previously been subject."239 Justice Kennedy warned that the Court's result in Lara could portend

233. Id.

234. Id.

235. Pilot Project for Tribal Jurisdiction Over Crimes of Domestic Violence, 78 Fed. Reg. 35,961 (June 14, 2013).

236. P.L. 113-4. See also Pilot Project for Tribal Jurisdiction Over Crimes of Domestic Violence, 78 Fed. Reg. 35,961.

237. United States v. Lara, 541 U.S. 193, 210 (2004).

238. Id. at 211 (Kennedy, J., concurring).

239. Id. at 213-14. 
an expansion of the doctrine of inherent tribal authority beyond traditional notions of self-government and that such an expansion of inherent tribal authority might be beyond the power of Congress. ${ }^{240} \mathrm{He}$ noted that if the issue presented were the power of Congress to subject American citizens to an extraconstitutional forum, "it would be a difficult question"; and that, as a result, the Court's overbroad formulation in Lara "on a point of major significance to our understanding and interpretation of the Constitution ... is most doubtful."241

But in fact, the Lara decision does subject American citizens, non-member Indians, to "extraconstitutional" fora. ${ }^{242}$ While Justice Breyer, writing for the majority, concluded that Lara did not directly present the question of whether the tribal prosecution might have violated Lara's due process or equal protection rights (because it was a challenge to the federal prosecution rather than the tribal), ${ }^{243}$ the result of Lara is that tribes currently exercise criminal jurisdiction over non-member Indians, with the explicit blessing of Congress and the implicit blessing of the Court.

Justice Kennedy's concurrence seems to suggest that the Court might be inclined to create a standard that accords greater constitutional "protection" from facing tribal criminal process to non-Indians than non-member Indians. ${ }^{244}$ While that result would by itself be highly suspect, perhaps some members of the Court envision, as one possible justification for differential treatment "protecting" non-Indians more than nonmember Indians, that tribal members have, by voluntarily enrolling in a federally recognized Indian tribe, effectively consented to tribal jurisdiction generally. ${ }^{245}$

In contrast to the courts, Congress is in a far better position to craft an informed and nuanced rule for deciding when non-Indians ought to be subjected to tribal court jurisdiction. The VAWA provisions for special domestic violence jurisdiction again illustrate Congress's ability to craft a far better proxy for effective consent to tribal criminal jurisdiction than mere enrollment: the jurisdiction depends on one's

240. Id. at $212,214$.

241. Id. at 211 .

242. Id. at 213.

243. Id. at 208-09 (majority opinion).

244. Id. at 212-13 (Kennedy, J., concurring).

245. Id. 
presence in Indian country and an intimate relationship with a tribal member. ${ }^{246}$ In addition, the new law is narrowly tailored to extend tribal criminal jurisdiction over non-Indians to crimes of domestic violence, which Congress has identified as an area of particular concern, and which by definition involve a consensual relationship with a tribal member. ${ }^{247}$ It does not broadly grant or withdraw, wholesale, tribal authority as past decisions of the Court have done. ${ }^{248}$

In contrast to the broad strokes of the Court, the new law tailors the jurisdiction to domestic violence offenses and defines "domestic violence" for purposes of tribes' special domestic violence criminal jurisdiction as follows:

The term domestic violence means violence committed by a current or former spouse or intimate partner of the victim, by a person with whom the victim shares a child in common, by a person who is cohabitating with or has cohabitated with the victim as a spouse or intimate partner, or by a person similarly situated to a spouse of the victim under the domestic- or family-violence laws of an Indian tribe that has jurisdiction where the violence occurs. ${ }^{249}$

The law places tailored restrictions on the tribe's exercise of special domestic violence jurisdiction. ${ }^{250} \mathrm{It}$ requires that, in order for a tribe to exercise jurisdiction, either the defendant or alleged victim must be a member of the participating tribe, or demonstrate "sufficient ties" to the tribe. 251 To enforce this nexus with the tribe exercising jurisdiction, the parties may bring a pre-trial motion requiring the tribe to demonstrate sufficient ties, such as whether the defendant or alleged victim resides in the Indian country of the participating tribe; is

246. Violence Against Women Reauthorization Act of 2013, Pub. L. No. 113-4, 127 Stat. 54 (codified as amended in scattered sections $42,25,22$, and 18 U.S.C.).

247. Id.

248. See Oliphant v. Suquamish Indian Tribe, 435 U.S. 191, 212 (1978) (holding that no tribe retained inherent authority to prosecute non-Indian offenders); Duro v. Reina, 495 U.S. 676, 688 (1990) (holding that no tribe retained inherent authority to prosecute non-member Indians).

249. Violence Against Women Reauthorization Act of 2013, Pub. L. No. 113-4, § 904, 127 Stat. 54 (codified as amended in scattered sections $42,25,22$, and 18 U.S.C.).

250. Id. Title IX.

251. Id. 
employed by the tribe; or is a spouse, intimate partner, or member of the tribe. ${ }^{252}$ The courts, in contrast, lack this ability to craft specific, flexible rules of this sort and thus are in a far worse position to accommodate the many competing interests at stake. The ability of Congress to closely tailor and condition the exercise of inherent authority therefore weighs in favor of the superior competence of Congress in setting the metes and bounds of inherent tribal authority. By its nature as a policymaking branch, Congress can fashion nuanced solutions that a court, constrained by the case or controversy before it, cannot. Whereas courts must essentially pick a winner and a loser in deciding a case in the adversarial system, Congress can balance competing interests in a way that both acknowledges tribal sovereignty and protects the due process concerns of nonIndians who may be subjected to the criminal process of a tribal court.

\section{Adapting to Changing Circumstances}

Congress is typically in a far better position than courts to respond to changing circumstances and emerging crises. ${ }^{253}$ While the opportunity to reverse an entrenched decision like Oliphant (even if the Court were to reimagine its perceptions of tribal institutional capacity, may never be presented) Congress can consider (and reconsider) the parameters of tribal sovereignty as circumstances warrant.

In contrast, the courts are necessarily limited to the cases and controversies that come before them. Courts do not have a similar ability to amend earlier rulings based simply on emerging crises or subsequent experience. Where Congress can be both proactive and reactive, the Court is constrained by the actual questions presented in litigation and limited by the remedies available to the parties to the litigation. Moreover, given the number of courts and limited Supreme Court review, the courts are ill-suited to provide solutions that address the diversity of tribal needs and capacities.

252. Id. § 904(b)(4)(B).

253. Indeed, in Garcia, the Supreme Court noted that one problem with tests often employed by courts to try to create judicially identifiable and stable standards, such as the "historical test" for traditional state functions, is that they explicitly preclude consideration of changes in circumstances. Garcia v. San Antonio Metro. Transit Auth., 469 U.S. 528, 543 (1985). 
Here again, the wave of violence against Native women serves as an important illustration of Congress's comparative competence. As noted above, the Senate Indian Affairs Committee hearing on violence against Native women presented a sobering picture of the consequences of the jurisdictional gap. ${ }^{254}$ Associate Attorney General Thomas J. Perrelli testified that "the current legal structure for prosecuting domestic violence in Indian country is not well suited to combating this pattern of escalating violence," citing a lack of federal resources and key gaps in federal law. ${ }^{255} \mathrm{He}$ argued that tribes should be full partners in the law enforcement response to this wave of violence and noted that "crime fighting tools currently available to [tribal] prosecutors differ vastly, depending on the race of the domestic-violence perpetrator."256

Congress's decision to enact the VAWA tribal jurisdiction provision may reflect its determination that the lack of an adequate legal response to domestic violence against Native women not only allows perpetrators to escape justice, it contributes to the systemic societal harm facing many tribal communities. ${ }^{257}$ At the hearing, Dr. Rose Weahkee, Director of Behavioral Health for the Indian Health Service, testified that there is a "tremendous physical and psychological toll that sexual assault and domestic violence take on individuals and society." 258 Dr. Weahkee also noted that children who have

254. See generally Native Women, supra note 4.

255. Id. at 9 (prepared statement of Thomas J. Perrelli, Assoc. Att'y Gen.).

256. Id. "If an Indian woman is battered by her husband or boyfriend, then the tribe typically can prosecute him if he is Indian. But absent an express Act of Congress, the tribe cannot prosecute a violently abusive husband or boyfriend if he is non-Indian. And recently, one federal court went so far as to hold that, in some circumstances, a tribal court could not even enter a civil protection order against a non-Indian husband.").

257. Id. at 31; S. REP. No. $112-265$, at 4 (2012) (Conf. Rep.) ("While the national crime rate has been on the decline in the last decade, native Americans experience violent crimes at a rate much higher than the general population.") (citing Steward Wakeling et al., Policing on American Indian Reservations, U.S. Dep't of Justice, Office of Justice Programs, Nat'l Institute of Justice 13 (July 2001)).

258. Native Women, supra note 4, at 31-32 (statement of Rose Weahkee, Ph.D., Dir. Div. of Behavioral Health, Indian Health Serv., U.S. Dep't of Health and Human Servs.) ("Besides the obvious costs of medical care and evidence collection, there is increasing evidence that interpersonal violence is associated with many common health problems, including obesity, hypertension, chronic pain, headaches, gastrointestinal problems, complications of pregnancy, post traumatic stress disorder, alcohol use disorders, depression and anxiety. All of these health 
witnessed domestic violence are at a significant risk of becoming themselves victims or perpetrators of violence, including special risks for developing depression and alcohol use disorders and dependence. ${ }^{259}$ The Committee also heard testimony from tribal leaders strongly urging Congress to take action to allow tribes to be partners in the effort to stem violence against Native women and to punish offenders who commit crimes of violence against tribal members. 260

Faced with the evidence of this epidemic of violence against Native women by non-Indian offenders and the weight of evidence of the broad societal costs of this gap in jurisdiction, Congress affirmed a special domestic violence jurisdiction as an exercise of inherent tribal authority to respond to the crisis. Congress could have chosen to delegate federal authority to tribes through cross-deputation agreements or provide civil remedies in the federal courts. Congress could have also authorized a public education campaign designed to deter potential domestic violence offenders on Indian reservations, or any number of other measures designed to address the crisis. However, Congress chose to empower tribes by removing restrictions on the exercise of inherent authority as the most effective mechanism for responding to the crisis. ${ }^{261}$ As various tribes qualify as "participating tribes" under the program and the Department of Justice works with tribes to implement the provisions, Congress is in a position to refine, expand, or even contract the special domestic violence provisions as

problems can impact an individual's family life and ability to work. The economic impact of the loss of work and productivity is enormous.") (citing Adverse Health Conditions and Health Risk Behaviors Associated, 57 MORBIDITY \& MORTALITY WKLY. REP. 113-17 (2008)).

259. Id. at 34 ("Our prevention and treatment efforts must also focus on children and adults who have already witnessed or experienced domestic violence and sexual assault. Our youth, who have witnessed domestic violence or who have experienced child abuse/sexual abuse including incest are at great risk of becoming victims or perpetrators of violence and sexual assault as adults. Girls who witness the domestic abuse of their mothers, or who are victims of childhood sexual abuse are at special risk of developing PTSD, depression, and alcohol use disorders including binge drinking and alcohol dependence.").

260. Id. at 44-58 (Statements of tribal leaders at hearing).

261. S. REP. No. $112-265$, at 17 (2012) (Conf. Rep.) ("Congress has much broader plenary authority to legislate over Indian affairs than it does delegating criminal enforcement powers that are reserved for the Federal Government. Recognizing and affirming a tribe's inherent power to exercise criminal jurisdiction over certain nonmembers is exactly what Congress did in the "Duro fix," which the Supreme Court upheld in United States v. Lara."). 
circumstances may warrant.

\section{The Prominence of Resource Allocation Issues}

Resource allocation questions are rightfully within the purview of Congress rather than the courts. Which branch holds the purse strings is, therefore, another measure in the calculus of institutional competence. ${ }^{262}$ Many of the decisions that must be made about the appropriate scope of inherent tribal authority necessarily turn on questions of resource allocation. The allocation of scarce resources is precisely the kind of "polycentric" problem Professor Fuller argues is "illsuited to the judicial capacity."263 In essence, these are problems where each decision may have "a different set of repercussions and might require in each instance a redefinition of the "parties affected," like a "spider web."264

For example, in the VAWA, Congress chose to use the mechanism of affirming tribal jurisdiction over non-Indians by removing restrictions on the exercise of inherent authority. ${ }^{265}$ Part of this calculus may reflect the recognition that prosecutions by U.S. Attorneys have been inadequate and that the demands on the financial and human resources of U.S. Attorneys and on the Federal Bureau of Investigation frequently leave tribal justice issues unaddressed. ${ }^{266}$ The resulting gap in enforcement allows non-Indian offenders to

262. Eric Biber, The Importance of Resource Allocation in Administrative Law, 60 ADMIN. L. REV. 1, 4-6 (2008) (discussing the role of judicial deference in questions of resource allocation in the administrative law context).

263. Fuller, supra note 116, at 395 (expressing the view that some "polycentric" problems, or problems with such "complex repercussions" that "adjudication[s] cannot encompass and take [them] into account," are ill-suited to the judicial capacity).

264. Id. ("A pull on one strand will distribute tensions after a complicated pattern throughout the web as a whole. Doubling the original pull will, in all likelihood, not simply double each of the resulting tensions but will rather create a different complicated pattern of tensions. . . This is a 'polycentric' situation because it is 'many-centered'-each crossing of strands is a distinct center for distributing tensions.").

265. Violence Against Women Reauthorization Act of 2013, Pub. L. No. 113-4, § 904, 127 Stat. 54 (codified as amended in scattered sections $42,25,22$, and 18 U.S.C.).

266. U.S. Gov'T ACCOUNTABILITY OFFICE, GAO-11-167R, U.S. DEPARTMENT OF JUSTICE DECLINATIONS OF INDIAN COUNTRY CRIMINAL MATTERS (2010), available at $\mathrm{http}: / / \mathrm{www}$.gao.gov/assets/100/97229.pdf. 
escape justice to an unacceptably large degree. ${ }^{267}$ Limitations on federal law enforcement and resources mean that the early incidents of assault within relationships, which tend to predict escalating violence, are not addressed in a timely way but are allowed to escalate to ever more serious assaults and murders. ${ }^{268}$ With the proper legal tools, tribes could intervene earlier in the pattern of violence, saving lives and preventing more serious trauma and injury. Because tribes are often geographically remote and culturally diverse, local tribal authorities are best positioned to formulate effective response strategies. Congress seems to be well within its resource allocation purview to decide that strengthening tribal institutions-like tribal courts and tribal law enforcement-is a better use of resources than diverting the resources from other federal law enforcement priorities at significant human and economic cost.

If, however, the Supreme Court rejects the VAWA tribal jurisdiction provision, it deprives Congress of its ability to address the tide of violence against Native women through its chosen allocation of responsibility and resources. Congress may be forced either to let the tide of violence continue unabated, or to allocate more federal resources to U.S. Attorneys to prosecute these crimes themselves, diverting the resources from other important federal priorities. The Court should not be pulling on those strands of the complicated web of resource allocation. Congress should not be given the choice of leaving tribes unable to provide basic public safety for their own members.

One could argue to the contrary that such sensitive issues of sovereignty ought not depend upon the changing landscape of resource issues, but rather, ought to be decided upon objective principles. Given that the decisions on the proper scope of inherent authority will often turn on the amount of resources Congress will otherwise be required to allocate to a problem, and the complex calculus of the consequences of such resource allocation issues, Congress is in the best position to make the inherent tribal authority determination.

267. Id.

268. S. REP. No. 112-265, at 26-27 (2012) (Conf. Rep.). 


\section{Subject Matter Expertise}

In the same way that agencies develop regulatory and interpretive expertise in certain areas of law that may entitle their statutory interpretation to some degree of deference from the courts, Congress's policy expertise and plenary authority as trustee may entitle its policy judgments to deference. ${ }^{269}$ Professor Horwitz discusses the "epistemic authority-based justification for deference" as encompassing the idea that courts "defer to other decisionmakers on epistemic grounds when they believe that the other decisionmaker has greater expertise at its command on the issue in question." 270 In the administrative law context, courts "regularly rely on the expertise of ... agencies in deferring to them." 271 Just as the court may be "ill-equipped to make independent determinations about various aspects of military life," courts have not demonstrated any particular competence for comprehending the complex issues of tribal life. ${ }^{272}$

At the same time, Congress has formally constituted committees: the Senate Indian Affairs Committee and the House Resources Committee, staffed by subject matter experts and professionals dedicated to the development of law and policy in the exercise of Congress's Indian affairs power. Representatives advocating for (and opposing) the widely-

269. See Chevron, U.S.A., Inc. v. Nat'l Resources Def. Council, Inc., 467 U.S. 837, 865-66 (1984) ("Judges are not experts in the field, and are not part of either political branch of the Government. . . . When a challenge to an agency construction of a statutory provision, fairly conceptualized, really centers on the wisdom of the agency's policy . . . the challenge must fail. In such a case, federal judges-who have no constituency-have a duty to respect legitimate policy choices made by those who do.").

270. Paul Horwitz, supra note 25, at 1085-87. Professor Horwitz argues that when courts defer to other decisionmakers on epistemic grounds "they are suggesting that some other decisionmaker actually possesses important information, experience, and skills that will help it decide some relevant question correctly. Second, they are suggesting that the other decisionmaker is not just a good one: it is also a superior decisionmaker, relative to the court." Id. at 1086. Examples may include the superior expertise of administrative agencies or the military to determine questions courts may be "ill-equipped" to answer.

271. Id.

272. Id. at 1087. See, e.g., Strate v. A-1 Contractors, 520 U.S. 438 (1997) (holding Tribe did not have a cognizable interest in adjudicating an accident involving a longstanding member of the reservation community); Atkinson Trading Co. v. Shirley, 532 U.S. 645 (2001) (holding Tribe did not have power to tax non-Indian guests of a hotel within the boundaries of the reservation at a facility served by the Tribe's public safety infrastructure and personnel). 
varied interests of the 566 federally recognized tribes have access to members of Congress. Congress is able to hold hearings to gather input and data from subject matter experts as it deliberates policy. Subject matter experts from the executive branch routinely brief members and staff involved in the development of legislation affecting tribes and offer comment on proposed legislation, combining the expertise and experience of the political branches. While courts may receive amicus briefs and expert reports related to a particular adjudicative question, there is no corresponding cadre of individuals with specialized expertise in Indian affairs within the federal court system.

In the enactment of the tribal jurisdiction provisions of VAWA, Congress held numerous hearings over several years and debated the language and mechanics of the provisions, the rights of non-Indians, and the role of tribal institutions. ${ }^{273}$ The final passage of the proposal represents the considered judgment of Congress after close and careful weighing of the facts and the variety of tools for addressing the issue. To the extent that any bill passed by Congress represents the consensus of the majority of legislators, this bill represents the consensus of the policymaking branch for developing a tailored response to a serious public safety concern. The superior subject-matter expertise of Congress as compared to the courts represents an additional factor weighing in favor of deference to the policy judgment of Congress in setting the bounds of inherent tribal authority.

\section{CONCLUSION}

The special domestic violence provisions in VAWA purport to affirm the inherent authority of tribes to exercise a limited criminal jurisdiction over all persons, even non-Indians, if the tribe demonstrates a sufficient nexus between the offender and the tribe and qualifies as a participating tribe by offering adequate protection for the due process rights of the accused. The controversial step by Congress alters the longstanding boundaries of inherent tribal authority, as described by the Supreme Court in Oliphant. It also amounts to an assertion

273. See e.g., Native Women, supra note 4; 159 CONG. REC. S571, 579 (daily ed. Feb. 11, 2013) (statement of Sen. Maria Cantwell). 
that Congress's Indian affairs power is broad enough to set the metes and bounds of inherent tribal authority beyond where the Supreme Court has set them. The VAWA provisions follow a similar assertion of authority to alter the boundaries of inherent tribal authority over non-member Indians in Lara, which the Court affirmed while signaling a hesitance to defer to a similar assertion of authority over non-Indians.

The comparative institutional competency framework set forth in Garcia for deciding sensitive questions about the complicated relationship between federal and state sovereigns provides an important model for how the Court should assess Congress's assertion of authority to define inherent tribal authority. The question of tribal authority likewise involves difficult questions about overlapping sovereignty. An examination of indicia of comparative competency suggests that Congress has the superior competence for determining inherent tribal authority questions and that Congress's recent decision to affirm inherent tribal authority in VAWA should be upheld. 